\title{
A revision of the swimming crabs of the Indo - West Pacific Xipbonectes bastatoides (Fabricius, 1798) species complex (Crustacea: Brachyura: Portunidae)
}

\author{
Ревизия комплекса видов крабов-плавунцов Xiphonectes \\ bastatoides (Fabricius, 1798) (Crustacea: Brachyura: Portunidae) \\ из Индо-Вестпацифики
}

\author{
Thanh Son Nguyen ${ }^{1}$, Peter K.L. $\mathrm{Ng}^{2}$

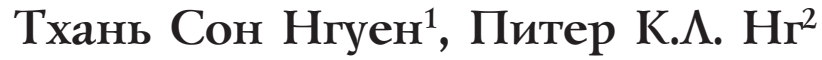

\footnotetext{
${ }^{1}$ Department of Biological Sciences, National University of Singapore; and Department of Applied Zoology, Faculty of Biology, VNU University of Science, Vietnam National University, Hanoi, 334 Nguyen Trai, Thanh Xuan, Hanoi, Vietnam. E-mail: nts@vnu.edu.vn

${ }^{2}$ Lee Kong Chian Natural History Museum, Faculty of Science, National University of Singapore, 2 Conservatory Drive, Singapore 117377, Republic of Singapore. E-mail: peterng@nus.edu.sg
}

KEY WORDS: Portunidae, Xiphonectes hastatoides, species complex, taxonomy, revision, new species, synonymies.

КЛЮЧЕВЫЕ СЛОВА: Portunidae, Xiphonectes hastatoides, видовой комплекс, систематика, ревизия, новые виды, синонимии.

ABSTRACT. The Xiphonectes hastatoides (Fabricius, 1798) species complex (Brachyura: Portunidae) is revised from a study of the types. Members of this species group are defined by the structures of the anterolateral margin, posteroexternal margin of the carapace, shape of the third maxilliped merus, as well as armatures of the carpus and merus of the cheliped, and carpus of the swimming leg. Of the seven currently known species four are recognised here: $X$. hastatoides s.str., X. arabicus (Nobili, 1905), X. unidens (Laurie, 1906), and X. pseudohastatoides (Yang et Tang, 2006). Three species, Neptunus (Hellenus) tweediei Shen, 1937, Portunus trilobatus Stephenson, 1972, and $P$. dayawanensis Chen, 1986, are synonymised under $X$. unidens, a species previously incorrectly synonymised under $X$. hastatoides. In addition, two new species are described, $X$. vassilyi sp.n. and $X$. subtilis sp.n., and can be distinguished from $X$. hastatoides s.str. by the structure of the median frontal teeth, posteroexternal spine on the carapace and structure of the male first gonopod.

How to cite this paper: Nguyen Thanh Son, $\mathrm{Ng}$ P.K.L. 2021. A revision of the swimming crabs of the Indo - West Pacific Xiphonectes hastatoides (Fabricius, 1798) species complex (Crustacea: Brachyura: Portunidae) // Arthropoda Selecta. Vol.30. No.3. P.386404. doi: 10.15298/arthsel.30.3.11

РЕЗЮМЕ. Видовой комплекс Xiphonectes hastatoides (Fabricius, 1798) (Brachyura: Portunidae) пересмотрен на основе изучения типового материала. Представители этой группы видов характеризуются структурой переднебокового края, заднего наружного края панциря, формой третьего меруса верхней челюсти, а также вооружением карпуса и меруса хелипеда и карпуса плавательных ног. В настоящее время признаны четыре вида рода Xiphonectes: $X$. hastatoides s.str., X. arabicus (Nobili, 1905), X. unidens (Laurie, 1906) и X. pseudohastatoides (Yang et Tang, 2006). Три вида, Neptunus (Hellenus) tweediei Shen, 1937, Portunus trilobatus Stephenson, 1972, и P. dayawanensis Chen, 1986, синонимизированы с $X$. unidens, видом, ранее неправильно синонимизированным с $X$. hastatoides. Кроме того, описаны два новых вида, $X$. vassilyi sp.n. и $X$. subtilis sp.n., и их можно отличить от $X$. hastatoides s.str. по строению средних передних зубов, задне-наружному позвоночнику на панцире и строению первого гонопода самца.

\section{Introduction}

Even with the substantial systematic revisions proposed by Schubart \& Reuschel [2009], Spiridonov et al. [2014], Evans [2018] and Spiridonov [2020], the Portunoidea is still considered a heterogeneous superfamily. In particular, the subgeneric system widely used for Portunus Weber, 1795, has been questioned. In their world checklist, $\mathrm{Ng}$ et al. [2008] followed this convention and recognised five subgenera of Portunus: P. (Achelous) De Haan, 1833; P. (Lupocycloporus) Alcock, 1899; P. (Monomia) Gistel, 1848; P. (Portunus) Weber, 1795; and P. (Xiphonectes) A. Milne-Edwards, 1873. In a genetic study of American portunids, Mantelatto et al. [2009] argued that $P$. (Achelous) should be recognised as a distinct genus (see also Mantelatto et al. [2018]). Following on this, as well as 
the observations in Mantelatto et al. [2007], Karasawa et al. [2008], Schubart \& Reuschel [2009]; Chertoprud et al. $[2012 \mathrm{~b}]$ argued that the subgeneric system used, e.g., P. (Monomia), was not practical, and gave Monomia generic status. Spiridonov et al. [2014], in their broad overview of the Portunoidea, treated all the subgenera as full genera, and transferred Lupocycloporus from the Portuninae to the Lupocyclinae Alcock, 1899. Koch \& Ďuriš [2018, 2019], Koch et al. [2015a, b, 2019] and Windsor et al. [2019] also treat Monomia and Xiphonectes as distinct genera. The various Portunus subgenera recognised are certainly relatively distinct and giving them genera status, at least based on their respective type species, does not pose serious problems. The challenge, however, will be to revise the constituent species assigned to Achelous, Mononia, Portunus and Xiphonectes, and to ascertain their intrageneric relationships.

Among Xiphonectes taxa, one of the more often reported species is $X$. hastatoides (Fabricius, 1798), a relatively small-sized (adult carapace width less than $50 \mathrm{~mm}$ ) taxon typically characterised by having a dark black spot on the dactylus of the swimming leg. It has been widely reported from the Indo-West Pacific region from South Africa to New Caledonia and Japan. The present study finds that $X$. hastatoides as presently recognised contains three different species, two of which are here recognised as new. Neptunus (Hellenus) hastatoides unidens Laurie, 1906, is also shown to be distinct from $X$. hastatoides and not a junior synonym, but is instead, the senior subjective synonym of $X$. tweediei (Shen, 1937). In addition, Portunus trilobatus Stephenson, 1972, and P. dayawanensis Chen, 1986, are also junior synonyms of $N$. unidens. The redefinition of $X$. hastatoides, diagnoses of the two new species and other members of the species in the group ( $X$. arabicus, $X$. pseudohastatoides, $X$. trilobatus and $X$. unidens) form the basis of the present paper.

\section{Material and methods}

Specimens examined are deposited in The Natural History Museum (NHM), London, U.K.; Queensland Museum (QM), Brisbane, Australia; Zoological Museum, University of Copenhagen (ZMUC), Copenhagen, Denmark; Zoological Museum of Kiel University (ZMK), Kiel, Germany; The Marine Biological Museum of the Chinese Academy of Sciences (MBMCAS) in the Institute of Oceanology, Qingdao, China; Ryukyu University Museum, Fujukan (RUMF), Okinawa, Japan; and Zoological Reference Collection (ZRC) of the Lee Kong Chian Natural History Museum, National University of Singapore. The abbreviation SRFRS is used for the now Singapore Regional Fisheries Research Station.

Measurements provided (in millimeters) are of the carapace width and length, respectively. In the occasional instance where the last anterolateral tooth is broken, only the carapace length is given. The abbreviations CW, CL, coll., G1, G2, ovig., fms, s.lat., s.str., stn and juv. are used for carapace width, carapace length, collected, male first gonopod, male second gonopod, ovigerous, fathoms, sensu lato, sensu stricto, station and juvenile, respectively. The term swimming leg is used for the last leg or pereiopod 5.

The shape of the G1 is a critical character, and as such, photographs of these structures are standardised: they are detached at the base, positioned to ensure the basal and distal parts are on the same plane and parallel with the camera/microscope lens surface. One key character used in this study is the form of the junction between the posterolateral margin and posterior carapace margin. In all the species in the present group, this junction forms a distinct right angle or is armed with a spine. For ease of discussion, this character is here referred to as the posteroexternal carapace angle.

The recognised species in the $X$. hastatoides species group are superficially similar in morphology, so only diagnostic characters will be given to avoid repetition. A complete description is only provided for the first species, $X$. hastatoides s.str. When various species are listed, names will be arranged by the year the taxon was described. Many previous workers have recorded $X$. hastatoides from IndoWest Pacific region but not all of them provided good descriptions and/or figures. Where material could not be reexamined, we have attempted to attribute literature records based on the descriptions, figures and/or geography. Where the identification of Xiphonectes taxa cannot be clarified, these specimens are referred to an incertae sedis section and discussed in full.

\section{Taxonomy}

Superfamily Portunoidea Rafinesque, 1815 Family Portunidae Rafinesque, 1815

Genus Xiphonectes A. Milne-Edwards, 1873

Xiphonectes A. Milne-Edwards, 1873.

TYPE SPECIES. Amphitrite vigilans Dana, 1852.

REMARKS. Xiphonectes A. Milne-Edwards, 1873, currently contains 34 species and subspecies: $X$. aculeatus Koch et Duriš, 2019, X. alcocki (Nobili, 1906), X. andersoni (De Man, 1887), X. arabicus (Nobili, 1905) $(=P$. (H.) acerbiterminalis Stephenson et Rees, 1967), X. brockii (De Man, 1887), X. dayawanensis (Chen, 1986), X. gracillimus (Stimpson, 1858), X. guinotae (Stephenson et Rees, 1961), X. hainanensis (Chen, 1986), X. hastatoides (Fabricius, 1798) (= P. hastatoides Weber, 1795), X. iranjae (Crosnier, 1962), X. latibrachium (Rathbun, 1906), X. longispinosus var. bidens (Laurie, 1906), X. l. longimerus (Spiridonov, 1994), X. longispinosus longispinosus (Dana, 1852) $(=A$. vigilans Dana, 1852; P. (X.) leptocheles A. Milne-Edwards, 1873), X. $l$. obtusidentatus Miers, 1884, X. macrophthalmus (Rathbun, 1906), X. mariei (Guinot, 1957), X. paralatibrachium (Crosnier, 2002), X. pseudohastatoides (Yang et Tang, 2006), X. pseudotenuipes (Spiridonov, 1999), X. pulchricristatus (Gordon, 1931) (= Neptunus (H.) alcocki Gordon, 1930), X. rugosus (A. Milne-Edwards, 1861), X. spiniferus (Stephenson et Rees, 1967), X. spinipes (Miers, 1886), X. stephenso$n i$ (Moosa, 1981) $(=P$. (H.) emarginatus Stephenson et Campbell, 1959), X. tenuicaudatus (Stephenson, 1961), X. tenuipes (De Haan, 1835), X. tridentatus (Yang, Dai et Song, 1979), X. trilobatus (Stephenson, 1972), X. tuberculosus (A. Milne-Edwards, 1861), X. tuerkayi Spiridonov, 2016, X. tweediei (Shen, 1937), and X. unidens (Laurie, 1906) (cf. Ng et al. [2008]; Koch, Duriš [2019]). All are characterised by the posteroexternal carapace angle being distinctly angular and/or armed with a spine. 
There is one group of species in Xiphonectes which is characterised by the dorsal carapace surface only has small granules (not distinct spinules and sharp tubercles); the anterolateral margin has nine distinct teeth of which the last one is the largest; the supraorbital margin is smooth or with a notch (not with a small tooth); the junction between the posterior and posterolateral borders of the carapace is armed with a spine; the anteroexternal angle of the merus of the third maxilliped is strongly produced, curved and arches over the tip of the exopod; the carpus of the cheliped possessing one spine or tooth on the outer margin; the posterior margin of the merus of the cheliped has two distinct spines; the posterior margin of the merus of the swimming leg has several spinules or is serrated (not one prominent spine) and the male pleon is distinctly T-shaped. This is here referred to as the $X$. hastatoides species-group, and six taxa are recognised: X. hastatoides Fabricius, 1798, X. arabicus (Nobili, 1905) $(=P .(H$.$) acerbiterminalis Stephenson et Rees, 1967),$ X. unidens (Laurie, 1906) (= Portunus tweediei Shen, 1937; $P$. trilobatus Stephenson, 1972; P. dayawanensis Chen, 1986), X. pseudohastatoides (Yang et Tang, 2006), X. vassilyi sp.n., and X. subtilis sp.n. (cf. Laurie [1906]; Shen [1937]; Apel, Spiridonov [1998]; Wong et al. [2010]). Two recent studies have clarified the taxonomy of some of these species: $X$. hastatoides and $X$. arabicus were discussed by Apel \& Spiridonov [1998], while X. hastatoides, X. dayawanensis and X. pseudohastatoides were studied by Wong et al. [2010]. Wong et al. [2010] noted that their specimens of " $X$. hastatoides" from Hong Kong and Taiwan were different from the types of the species from India and $X$. hastatoides was a cryptic species complex. The present paper revises the taxonomy of $X$. hastatoides and its allied species.

\section{Xiphonectes hastatoides (Fabricius, 1798) s.str. Figs 1, 3A, 3E, 4A, 6A.}

Portunus hastatoides Fabricius, 1798: 368; Stephenson, Rees, 1967a: 27; Chhapgar, 1968: 612; Chhapgar, 1969: 612, pl. 2 fig. h; Zarenkov, 1969: 14; Thomas, 1969: 45; Stephenson, 1972a: 136 (part); 1972b: 14 (key), 40; Devi, 1993: 536; Bhadra, 1995: 255; Bhadra, 1998: 410; Deb, 1999: 352; Dev Roy, Nandi, 2007: 176; Kumar et al., 2007: 286; Wong et al., 2010: fig. 3A, B.

Neptunus (Amphitrite) hastatoides - Miers, 1886: 175; De Man, 1895: 557.

Neptunus hastatoides — Henderson, 1893: 368.

Neptunus (Hellenus) hastatoides - Alcock, 1899: 38; Laurie, 1906: 414, fig. 8; Shen, 1937: 107, text-figs 5, 8g, h.

Neptunus (Hellenus) hastoides (sic) - Chopra, 1935: 477, 478 , text-fig 4.

Portunus (Xiphonectes) hastatoides - Sethuramalingam, Khan, 1991: pl. 19 fig. 5; Davie, 2002: 468; Dev Roy, Nandi, 2008: 198, 204; 2012: 204; Ng et al., 2008: 152; Dev Roy, 2013: 153, 157; Dev Roy et al., 2017: 1; Dev Roy, Rath, 2017: 96; Naderloo, 2017: 202, fig. 20.22e, fig. 20.39 .

Xiphonectes hastatoides — Trivedi et al., 2018: 70.

MATERIAL EXAMINED. Lectotype (here designated): $10^{7}$ $(41.7 \times 20.5 \mathrm{~mm})($ ZMUC), Tranquebar, southeast India. Paralectotypes (here designated): $4 \sigma^{7} \sigma^{7}(35.0 \times 17.0 \mathrm{~mm} ; 38.5 \times 20.0 \mathrm{~mm}$; $32.0 \times 14.0 \mathrm{~mm} ; 39.0 \times 19.0 \mathrm{~mm})\left(\right.$ ZMUC), $2 \sigma^{7} \sigma^{7}(36.0 \times 19.0 \mathrm{~mm}$; $39.0 \times 17.0 \mathrm{~mm})(\mathrm{ZMK})$, same data as lectotype. Others - India: $1 \sigma^{7}$ (ZRC 2019.0527), Tranquebar port, from fishermen, shallow waters, Tamil Nadu, India, coll. R. Ravinesh, 02.2019; Peninsular Malaysia: $13 \sigma^{7} \sigma^{7}(40.6 \times 22.4 \mathrm{~mm} ; 39.6 \times 22.5 \mathrm{~mm} ; 38.2 \times 20.9 \mathrm{~mm}$; $40.2 \times 21.2 \mathrm{~mm} ; 36.1 \times 19.7 \mathrm{~mm} ; 41.2 \times 22.7 \mathrm{~mm} ; 37.7 \times 20.6 \mathrm{~mm}$; $36.1 \times 19.6 \mathrm{~mm} ; 38.4 \times 21.2 \mathrm{~mm} ; 39.6 \times 22.1 \mathrm{~mm} ; 38.4 \times 20.7 \mathrm{~mm}$; $40.8 \times 22 \mathrm{~mm} ; 40.7 \times 20.6 \mathrm{~mm}), 9$ 우 $(38.8 \times 20.5 \mathrm{~mm} ; 36.2 \times 20.1$ $\mathrm{mm} ; 35.0 \times 19.7 \mathrm{~mm} ; 34.4 \times 19.0 \mathrm{~mm} ; 34.1 \times 18.8 \mathrm{~mm} ; 35.8 \times 17.9$ $\mathrm{mm} ; 36.5 \times 20.4 \mathrm{~mm} ; 38.8 \times 21.1 \mathrm{~mm} ; 32.6 \times 17.0 \mathrm{~mm}), 8$ ovig. .
$(38.8 \times 21.0 \mathrm{~mm} ; 37.2 \times 20.1 \mathrm{~mm} ; 36.9 \times 20.0 \mathrm{~mm} ; 36.8 \times 19.4 \mathrm{~mm}$; $35.2 \times 19.5 \mathrm{~mm} ; 33.5 \times 17.9 \mathrm{~mm} ; 32.9 \times 17.7 \mathrm{~mm} ; 38.8 \times 20.7 \mathrm{~mm})$ (ZRC 2000.1396), Penang, Teluk Bahang port, trawler (coastal catch from sea off northwestern Penang), coll. N. Sivasothi \& K.L. Yeo, 25.04.2000; $2 \sigma^{7} \sigma^{7}$ (ZRC 1965.10.21.21-22), in fish trap, Penang, 4-5 fms, coll. M.W.F. Tweedie, 06.1934; $3 \sigma^{7} \sigma^{7}, 6$ 우 (all poorly preserved) (ZRC 1985.869-877), Batu Maung, Penang, coll. SRFRS, $1960 \mathrm{~s} ; 10^{7}(38.9 \times 20.7 \mathrm{~mm})($ ZRC 2000.1418$)$, southwestern Penang, fishing village at Gertak Sanggul, gill-net, coll. N. Sivasothi \& K.L. Yeo, 26.04.2000; 6 $0^{\top} \sigma^{\top}, 9+0$ (ZRC 2021.0432), Johor, Pontian, coll. P.K.L. Ng, 02.1993; $6 \mathrm{O}^{\top} \mathrm{O}^{7}$, 3 +9 (ZRC 2021.0437), Johor, Pontian, $31 \mathrm{~m}$, coll. D. Wee, 13.07.1993; Singapore: $8 \sigma^{7} \sigma^{7}$ (largest $\left.40.2 \times 21.6 \mathrm{~mm}\right), 3$ 우 $($ ZRC 1965.10.21.110), Siglap, coll. M.W.F. Tweedie, 12.1933, 07.1934; $10^{7}$ (damaged) (ZRC 1985.886), station B50, mud, off Tanjong Rhu, coll. SRFRS, 1960s; $1+$ (soft) (ZRC 1985.864), Bedok, coll. D.S. Johnson, 1960s; 1 옹 (soft) (ZRC 1985.885), clean substrate, stn B79, off Tanjong Stapa, $23 \mathrm{fms}$, coll. SRFRS, 06.1963; 10 , 1 smallo (soft) (ZRC 1985.867-868), hard substrate with gorgonians, off Damar Laut, 5-8 fms, coll. SRFRS, 06.1963; $2 \sigma^{7} \sigma^{7}$ (ZRC 1985.1910-1911), off Changi Point, coll. P.K.L. Ng, 9.05.1982; $10^{7}$ (ZRC 1985.881), mud substrate, station B43, Angler's Beach, off Changi, coll. SRFRS, 06.1963; $2 \sigma^{\top} \sigma^{\top}$, 1 우 (ZRC 1985.887889), muddy-sandy substrate, off Tanah Merah and Johore Shoal, coll. J.R. Hendrickson, 06.1963; 10', 1 ㅇ (ZRC 2021.0429), stn DW27, substrate with Placuna, east of Chek Jawa, Pulau Ubin, Singapore, $01^{\circ} 24.927^{\prime} \mathrm{N} 103^{\circ} 59.980^{\prime} \mathrm{E}$ to $01^{\circ} 25.273^{\prime} \mathrm{N} 103^{\circ}$ 59.692'E, 9.9-19.1 m, coll. Comprehensive Marine Biodiversity Survey, 18.10.2012; 1 ovig.+ (ZRC 2021.0430), stn DW28, sand and mud substrate, eastern side of Chek Jawa, Pulau Ubin, $1^{\circ} 25$. $295^{\prime} \mathrm{N} 103^{\circ} 59.645^{\prime} \mathrm{E}$ to $1^{\circ} 25.082^{\prime} \mathrm{N} 103^{\circ} 59.774^{\prime} \mathrm{E}$, trawl, coll. Comprehensive Marine Biodiversity Survey, 18.10.2012; 1?(ZRC 2021. 0440), stn T21, off Coney Island, 10-15 m, coll. Comprehensive Marine Biodiversity Survey, 8.03.2012; 10', 2 juv. .+ (ZRC 1985. $878-880)$, stns B74 and B75, on clean bottom, south of Singapore, coll. SRFRS, 06.1963; 1 juv. ${ }^{7}$ (ZRC 1993.7464), Southern Islands, coll. P.K.L. Ng, 03.1985; 1 juv. O' (ZRC 1993.136), Johor Shoal, coll. P.K.L. Ng, 05.1992; $2 \sigma^{7} \sigma^{7}$ (ZRC 1985.865-866), Singapore, $18 \mathrm{fms}$, coll. SRFRS, 11.1955; 1 ovig. (ZRC 1965.10. 21.24), off Changi, coll. N. Shark, 21.01.1926; 2 juv. $\sigma^{\top} \sigma^{\top}, 1$ juv. (ZRC 1985.882-884), station B49, muddy-sand substratum with Enhalus, off Siglap Obelisk, 1-4 fms, coll. SRFRS, 06.1963; $10^{7}$ (ZRC 2000.1180), off Changi, coll. Kah Wee \& Siow Koon, $7.06 .2000 ; 5 \sigma^{7} \sigma^{7}(43.7 \times 24.3 \mathrm{~mm} ; 41.9 \times 23.4 \mathrm{~mm} ; 45.9 \times 24.4 \mathrm{~mm}$; $43.0 \times 23.1 \mathrm{~mm} ; 41.5 \times 22.3 \mathrm{~mm}), 2$ ovig. + + $(44.8 \times 23.0 \mathrm{~mm} ; 39.7 \times$ $20.2 \mathrm{~mm}$ ) (ZRC 1984.349-362), South China Sea near Horsburgh Lighthouse, coll. H. Huat, 26.11.1982 - 15.12.1982; 1우 (ZRC 1984.6390), South China Sea near Horsburgh Lighthouse, coll. H. Huat, 28.08.1983; Indonesia: 2 juv. $\sigma^{7} \sigma^{7}$ (ZRC 1999.0293), $\mathrm{Pu}$ Maoi, Pulau Bintan, Riau Islands, coll. P.K.L. Ng et al., 07.1995; Thailand: 1 ㅇ $(31.9 \times 16.3 \mathrm{~mm})$ (ZRC 2000.0843), Phuket, Pichai port (from Andaman Sea), coll. P.K.L. Ng et al., 3-6.05.2000; $10 \sigma^{7} \sigma^{7}(44.1 \times 22.4 \mathrm{~mm} ; 43.8 \times 23.5 \mathrm{~mm} ; 44.5 \times 23.6 \mathrm{~mm} ; 46.5 \times 24.2$ $\mathrm{mm} ; 41.9 \times 22.9 \mathrm{~mm}) ; 7$ 우 $(36 \times 18.7 \mathrm{~mm} ; 35.6 \times 18.7 \mathrm{~mm} ; 33.5 \times 17.6$ $\mathrm{mm} ; 31.9 \times 16.2 \mathrm{~mm} ; 36.5 \times 18.6 \mathrm{~mm} ; 32.8 \times 16.9 \mathrm{~mm} ; 25.8 \times 13.2$ $\mathrm{mm}), 2$ ovig. 우 $(34.0 \times 17.1 \mathrm{~mm} ; 31.4 \times 15.3 \mathrm{~mm})($ ZRC 2000.0780$)$, Phuket, Pichai port (from Andaman Sea), coll. N.K. Ng et K.L. Yeo et al., 17-20.01.2000; $2 \sigma^{7} \Im^{7}, 2$, 9 (ZRC 1998.1128), Phuket, Pichai port (from Andaman Sea), coll. P. Chaitiamvong et al., 12.1998; 10', 2 ovig. OO+ (ZRC 1999.0217), Phuket, Pichai port (from Andaman Sea), coll. H.H. Tan, 04.1999; $5 \sigma^{7} \sigma^{7}, 3$ 우 (ZRC 1992.1033210339), Pattaya port, from trawlers, coll. P.K.L. Ng \& L.B. Holthuis, 25.12.1991; $10^{7}$ (ZRC 1999.0425), Songkhla port, Thailand, coll. H.H. Tan, 27.10.1998; 2 OO (ZRC 1998.1169), Angsila port, Chonburi Province, coll. P.K.L. Ng, 29.09.1998; $3 \sigma^{7} \sigma^{7}$ (2 with rhizocephalan), 2申O, 1 ovig. + (ZRC 2021.0438), Si Racha port, Chonburi Province, 20 m, coll. P.K.L. Ng, 22.02.2000; Cambodia: $10^{7}$ (ZRC 2021.0378), Tropaing Sangke commercial fishery, $10^{\circ} 34^{\prime} 7.01^{\prime \prime} \mathrm{N} 104^{\circ} 14^{\prime} 33.21^{\prime \prime} \mathrm{E}$, coll. D. Yeo \& T. Naruse, 27.12. 2010; Vietnam: $10^{7}$ (ZRC 2018.1280), Phu Quoc Island, Duong Dong market, $10^{\circ} 13.249^{\prime} \mathrm{N} 103^{\circ} 57.531^{\prime} \mathrm{E}$, coll. D. Yeo et al., 30. 11.2010 . 


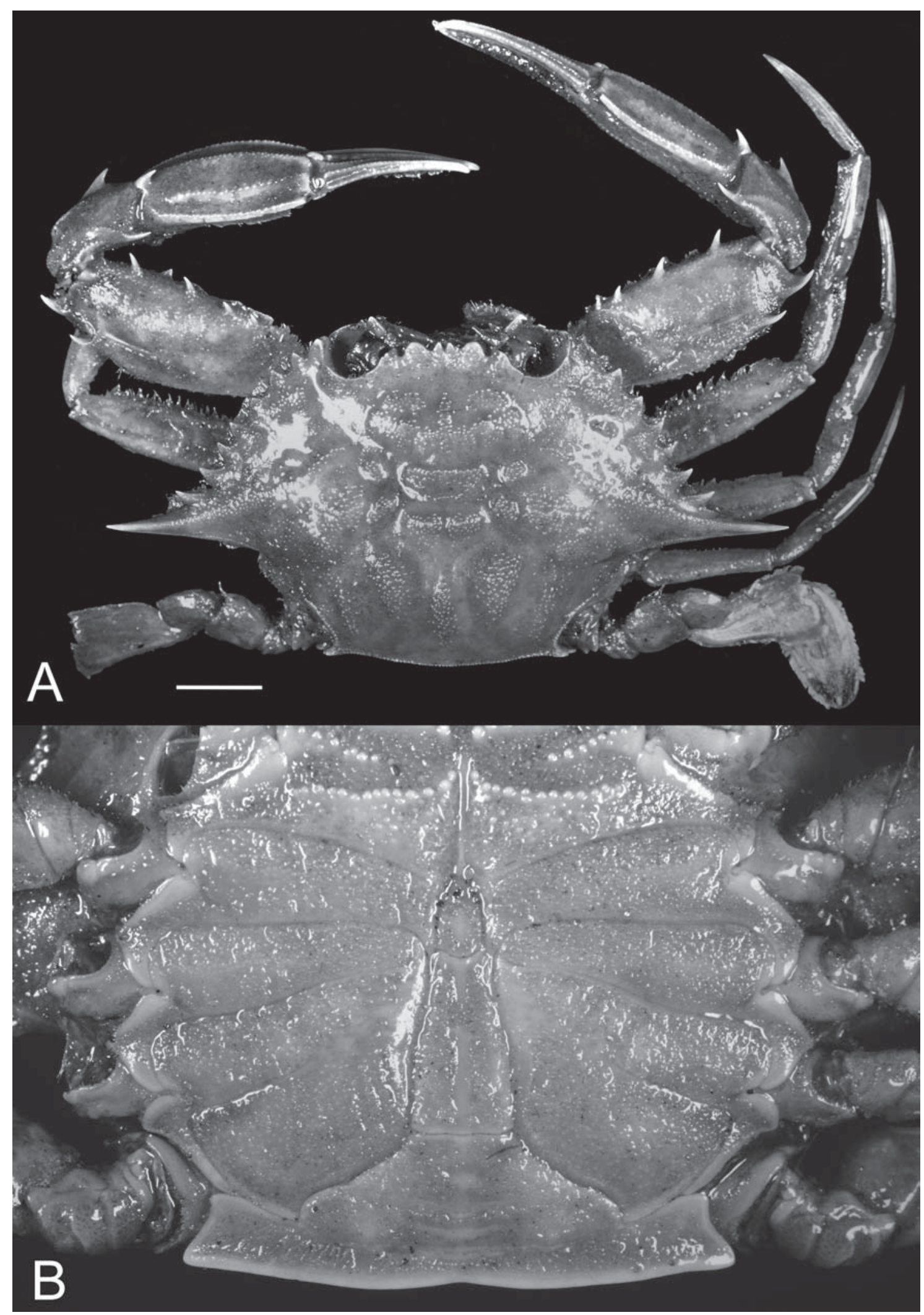

Fig. 1. Xiphonectes hastatoides (Fabricius, 1798), lectotype $\mathrm{O}^{7}(41.7 \times 20.5 \mathrm{~mm})(\mathrm{ZMUC})$, India: A — overall habitus; B — thoracic sternum and pleon.

Pис. 1. Xiphonectes hastatoides (Fabricius, 1798), лектотип О7 (41,7×20,5 мм) (ZMUC), Индия: А — общий вид; Б — грудные стерниты и плеон. 


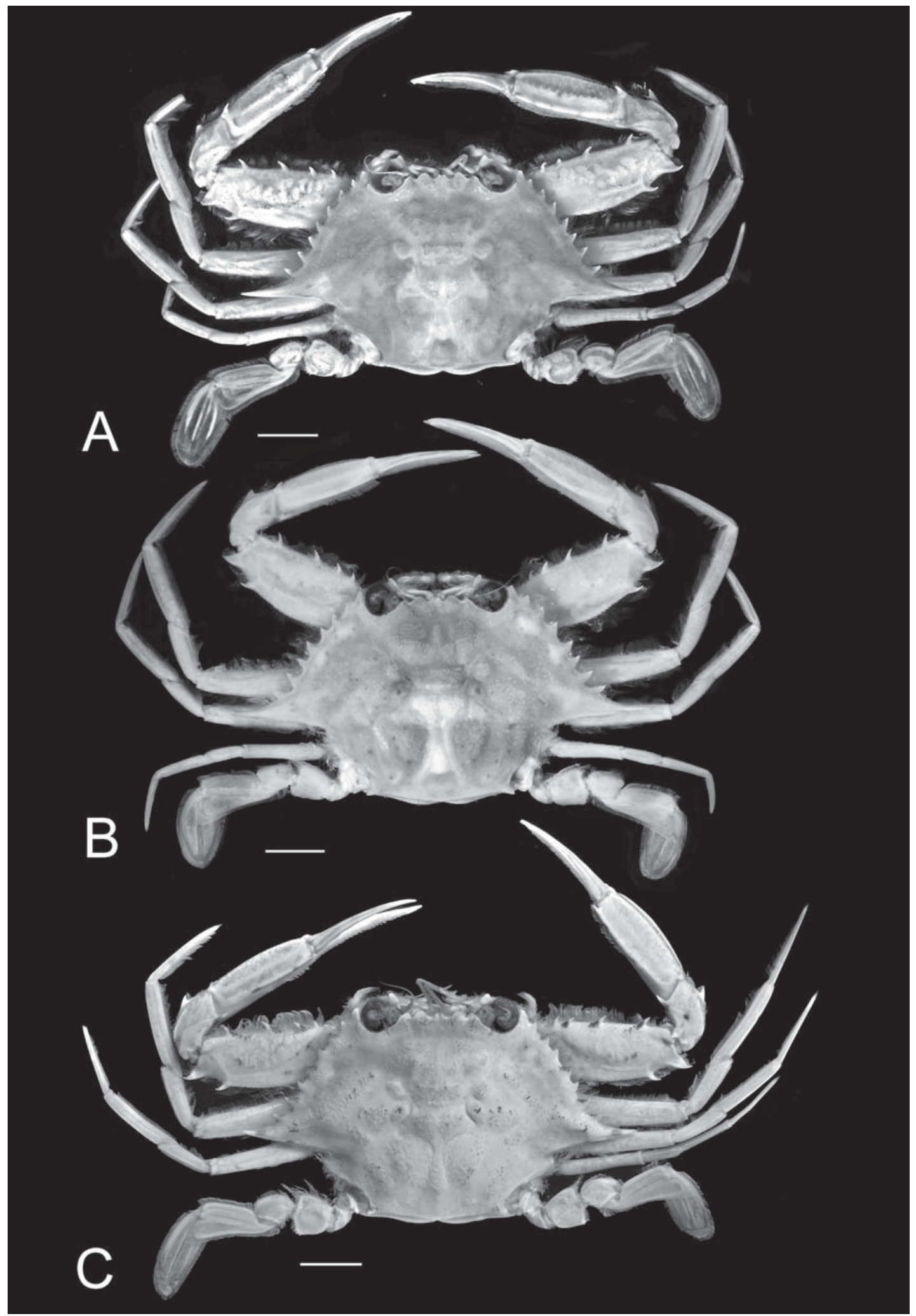

Fig. 2. Overall habitus: A — Xiphonectes vassilyi sp.n., holotype $\sigma^{7}(33.4 \times 16.0 \mathrm{~mm})($ ZRC 2009.0888), South Africa; B — X. subtilis sp.n., holotype Or $^{\top}(35.1 \times 17.3 \mathrm{~mm})($ ZRC 2003.0527), Indonesia; C - X. subtilis sp.n., Ơ $(32.0 \times 16.7 \mathrm{~mm})($ ZRC 1995.629), Taiwan. Scales $=5.0 \mathrm{~mm}$.

Рис. 2. Общий вид: А - Xiphonectes vassilyi sp.n., голотип О (33,4×16,0 мм) (ZRC 2009.0888), Южная Африка; В - X. subtilis sp.n., голотип О7 (35,1×17,3 мм) (ZRC 2003.0527), Индонезия; C - X. subtilis sp.n., О7 (32,0×16,7 мм) (ZRC 1995.629), Тайвань. Масштаб 5.0 мм. 

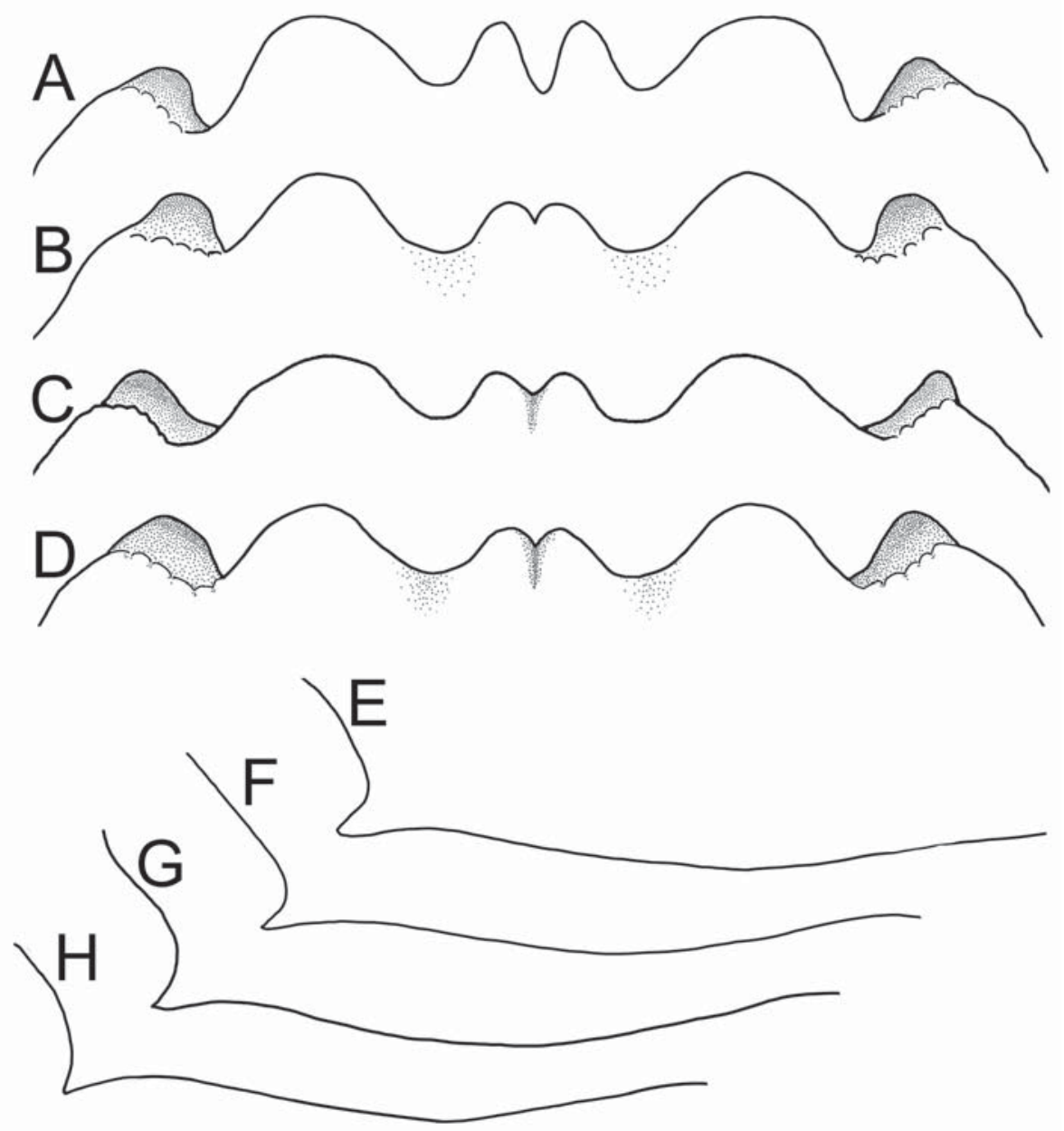

Fig. 3. Dorsal view of frontal margin (A-D), dorsal view of posterior carapace margin and posteroexternal carapace angle (E-H): A, E Xiphonectes hastatoides (Fabricius, 1798), s.str., lectotype $\sigma^{7}(41.7 \times 20.5 \mathrm{~mm})$ (ZMUC), India; B, F - X. vassilyi sp.n., holotype $\bigcirc^{7}$ $(33.4 \times 16.0 \mathrm{~mm})($ ZRC 2009.0888), South Africa; C, G - X. subtilis sp.n., holotype O' (35.1×17.3 mm) (ZRC 2003.0527), Indonesia; D, $\mathrm{H}-$ X. subtilis sp.n., Oフ $(32.0 \times 16.7 \mathrm{~mm})(\mathrm{ZRC} 1995.629)$, Taiwan.

Рис. 3. Дорсальный вид лобного края (A-D), дорсальный вид заднего края и заднего наружного угола карапскса (E-H): A, E Xiphonectes hastatoides (Fabricius, 1798) s.str., лектотип О (71,7×20,5 мм) (ZMUC), Индия; B, F - X. vassilyi sp.n., голотип О (33,4×16,0 мм) (ZRC 2009.0888), Южная Африка; C, G - X. subtilis sp.n., голотип О (35,1×17,3 мм) (ZRC 2003.0527), Индонезия; D, H - X. subtilis sp.n., O’ (32,0×16,7 мм) (ZRC 1995.629), Тайвань.

DIAGNOSIS. Small-sized species, largest specimen 46.5 $\mathrm{mm}$ in carapace width (ZRC 2000.0780). Dorsal surface of carapace covered with small rounded granules, scattered short pubescence. Frontal margin with 4 lobes, median pair acute, subequal to submedian pair but relatively narrower; separated by deep V-shaped notch (Fig. 3A). Anterolateral margin gently convex, with 9 teeth, last tooth longest, spiniform (Fig. 1A). Posterior carapace margin appears straight in posterior view (Fig. 4A); posteroexternal carapace angle with spine directed obliquely laterally, usually directed laterally, rarely curving upwards (Figs 3E, 4A). Tip of dactylus of swimming leg with prominent dark spot. G1 short, stout, tapering, strongly curved at about $2 / 3$ length from basal part, forming ca. $90^{\circ}$ angle (Fig. 6A).

DESCRIPTION. Dorsal surface of carapace slightly pubescent. Regions moderately well defined; gastric, cardiac, lateral, and median postcardiac regions elevated, separated by distinct grooves, with rounded granules (Fig. 1A). Front with 4 teeth; median teeth quite acute, tip rounded, as prom- inent as lateral teeth, separated by deep V-shaped notch; lateral pair distinctly broader, rounded (Fig. 3A). Supraorbital margin with 2 fissures.

Anterolateral margin gently convex, with 9 teeth, increasingly more acute from first to last; last tooth longest, sharpest, directed laterally; in smaller specimens, ratio of length of last anterolateral tooth to body width larger, becoming relatively shorter in large specimens. In dorsal view, posterior margin of carapace gently convex posteriorly, appears almost straight or gently convex from posterior view; posteroexternal carapace angle produced to form spine, usually directed obliquely laterally, rarely curved upwards (Figs $1 \mathrm{~A}, 3 \mathrm{E}, 4 \mathrm{~A})$; spine varies from blunt to acute. Antero-external angle of merus of third maxilliped strongly produced laterally.

Chelipeds slender, palm slightly less massive than arm. Merus with 4 spines on anterior border, 2 long sharp spines on posterodistal end. Upper surface of carpus with granulated carinae, with 2 spines and 2 beaded ridges. Manus slen- 


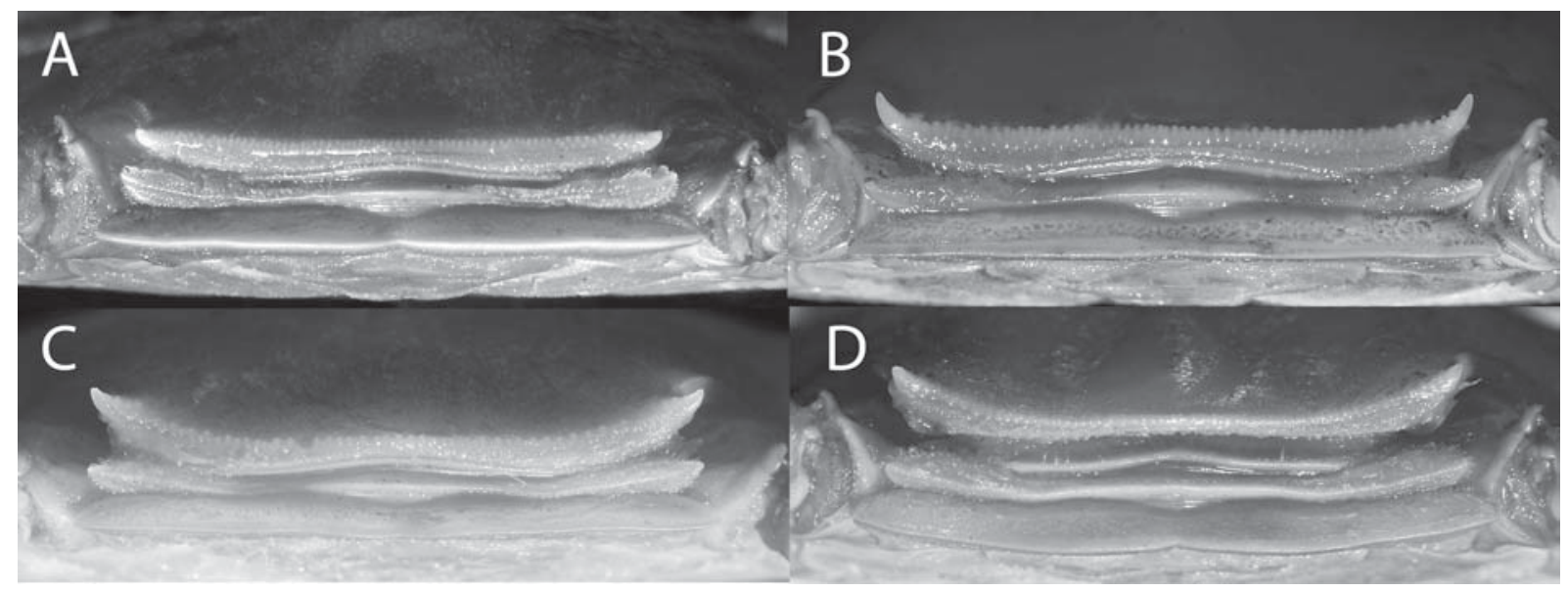

Fig 4. Rear view of posterior border of carapace: A - Xiphonectes hastatoides (Fabricius, 1798) s.str. (40.6 $\times 22.4 \mathrm{~mm})($ ZRC 2000.1396), India; B - X. vassilyi sp.n., holotype $\sigma^{7}(33.4 \times 16.0 \mathrm{~mm})\left(\right.$ ZRC 2009.0888), South Africa; C $-X$. subtilis sp.n., holotype $\sigma^{7}$ $(35.1 \times 17.3 \mathrm{~mm})($ ZRC 2003.0527), Indonesia; D - X. subtilis sp.n., ơ (32.0×16.7 mm) (1995.629), Taiwan.

Рис. 4. Вид сзади задней границы карапакса: A - Xiphonectes hastatoides (Fabricius, 1798) s.str. (40,6×22,4 мм) (ZRC 2000.1396), Индия; В - X. vassilyi sp.n., голотип о (33,4×16,0 мм) (ZRC 2009.0888), Южная Африка; C - X. subtilis sp.n., голотип О’ (35,1×17,3 мм) (ZRC 2003.0527), Индонезия; D - X. subtilis sp.n., o (32,0×16,7 мм) (1995.629), Тайвань.

der, upper surface with 3 low granulated carinae, with only inner one terminating in spine. Outer surface of hand with 1 well-developed carina. Fingers with inner margins dentate, teeth interlocking when closed.

Swimming leg with short merus, posterodistal border serrated. Remaining segments unarmed, bearing only setae. Distal portion of dactylus with a dark spot.

Thoracic sternum almost flat; anterior sternites (sternites 1-4) of large males with several transverse rows of larger granules, granules relatively smaller in females and juvenile specimens. Male pleon inverted T-shape; somite 6 and telson twice as long as broad (Fig. 1B).

G1 short, stout, tapering, strongly curved at about twothirds from basal part, forming ca. $90^{\circ}$ angle, tip directed laterally (Fig. 6A). G2 short.

REMARKS. Fabricius [1798] described the species from an unspecified number of specimens from Tranquebar, southeast India (I.K. Daldorff collection), but he did not designate any types. In ZMUC and ZMK are seven specimens, all of which are syntypes. The best preserved specimen, a male measuring 41.7 by $20.5 \mathrm{~mm}$ from the ZMUC is here selected as the lectotype. The remaining six male specimens are paralectotypes $(35.0 \times 17.0 \mathrm{~mm} ; 38.5 \times 20.0 \mathrm{~mm} ; 32.0 \times 14.0$ $\mathrm{mm} ; 39.0 \times 19.0 \mathrm{~mm} ; 36.0 \times 19.0 \mathrm{~mm} ; 39.0 \times 17.0 \mathrm{~mm})$.

Xiphonectes hastatoides s.str. can be distinguished from the two new species described here in having the median frontal teeth acute and as long as the submedian ones, and in having the spine at the posteroexternal carapace angle straighter and not prominently curved upwards (Figs 1A, $3 \mathrm{~A}, 4 \mathrm{~A})$. It also has the proportionately stoutest $\mathrm{G} 1$ of the three species with the distal slender part curving at almost right angles and the tip directed laterally (Fig. 6A). All the specimens examined, including the type series, also have a prominent dark spot on the swimming dactylus. Xiphonectes vassilyi sp.n. from South Africa is easily distinguished from $X$. subtilis sp.n. in having the spine at the posteroexternal angle of the carapace prominently curving upwards (Fig. 4B), its G1 is more relatively more slender and gently curved (Fig. 6B), and its swimming dactylus is not pigmented. Xiphonectes subtilis sp.n. has the spine at the posteroexter- nal angle of the carapace distinctly curving upwards (Fig. $4 \mathrm{C}, \mathrm{D})$ and has a more slender G1 which is less curved and with the distal part gently curved upwards (Fig. 6C, D).

The records from Singapore are all $X$. hastatoides s.str. Shen [1937: fig. 5a] shows clearly that Singapore specimens have a spine at the posteroexternal carapace angle but this is still relatively lower than those on $X$. subtilis. The G1 he figured [Shen, 1937: fig. 8g, h] appears somewhat slender but it is not accurate as it is actually stout like in typical $X$. hastatoides from India (Fig. 6A). There are also specimens clearly referable to $P$. hastatoides s.str. from southern Vietnam and Cambodia.

DISTRIBUTION. This species has been recorded from all over the Indo-West Pacific region, South Africa [Barnard, 1950], Madagascar [Crosnier, 1962], Persian Gulf [Stephensen, 1946; Apel, Spiridonov, 1998] to Australia, New Caledonia [Moosa, 1995], Gulf of Thailand [Stephenson, 1967], up to China and Japan [Sakai, 1939, 1976; Stephenson, Rees, 1967; Dai, Yang, 1991]. In this study, $X$. hastatoides s.str. is restricted from to waters from central Indian Ocean to parts of Southeast Asia. Western Indian Ocean, India, Sri Lanka, west cost of Peninsular Malaysia, Singapore, Thailand, Cambodia and southern Vietnam.

\section{Xiphonectes vassilyi sp.n.}

Figs 2A, 3B, 3F, 4B, 6B.

Hellenus hastatoides — Barnard, 1950: 158-159. [not P. hastatoides Fabricius, 1798]

Portunus hastatoides - Crosnier, 1962: 68-69, figs 96, 109, 117, 122-123; Stephenson, 1972a: 136 (part); Kensley, 1981: 42.

Portunus (Xiphonectes) hastatoides - Emmerson, 2016: 608, unnumbered figure.

MATERIAL EXAMINED. Holotype, $O^{7}(33.4 \times 16.0 \mathrm{~mm})($ ZRC 2009.0888a), South Africa, coll. S. Fennessy, 7.12.2006. Paratypes: $20^{7} \sigma^{7}(35.2 \times 16.4 \mathrm{~mm}, 33.4 \times 15.6 \mathrm{~mm}), 1$ 우 $(29.0 \times 13.2 \mathrm{~mm})($ ZRC 2021.0374), same data as holotype. Others - South Africa: $30^{7} 0^{7}$, 2 우 (ZRC 2013.1539), $18 \mathrm{~m}$, trawl, coll. S. Fennessy, 19.03.2010.

DIAGNOSIS. Frontal margin with 4 rounded tip teeth. Median pair smaller, length about half of submedian pair, notch between median teeth shallow, about half of length of 


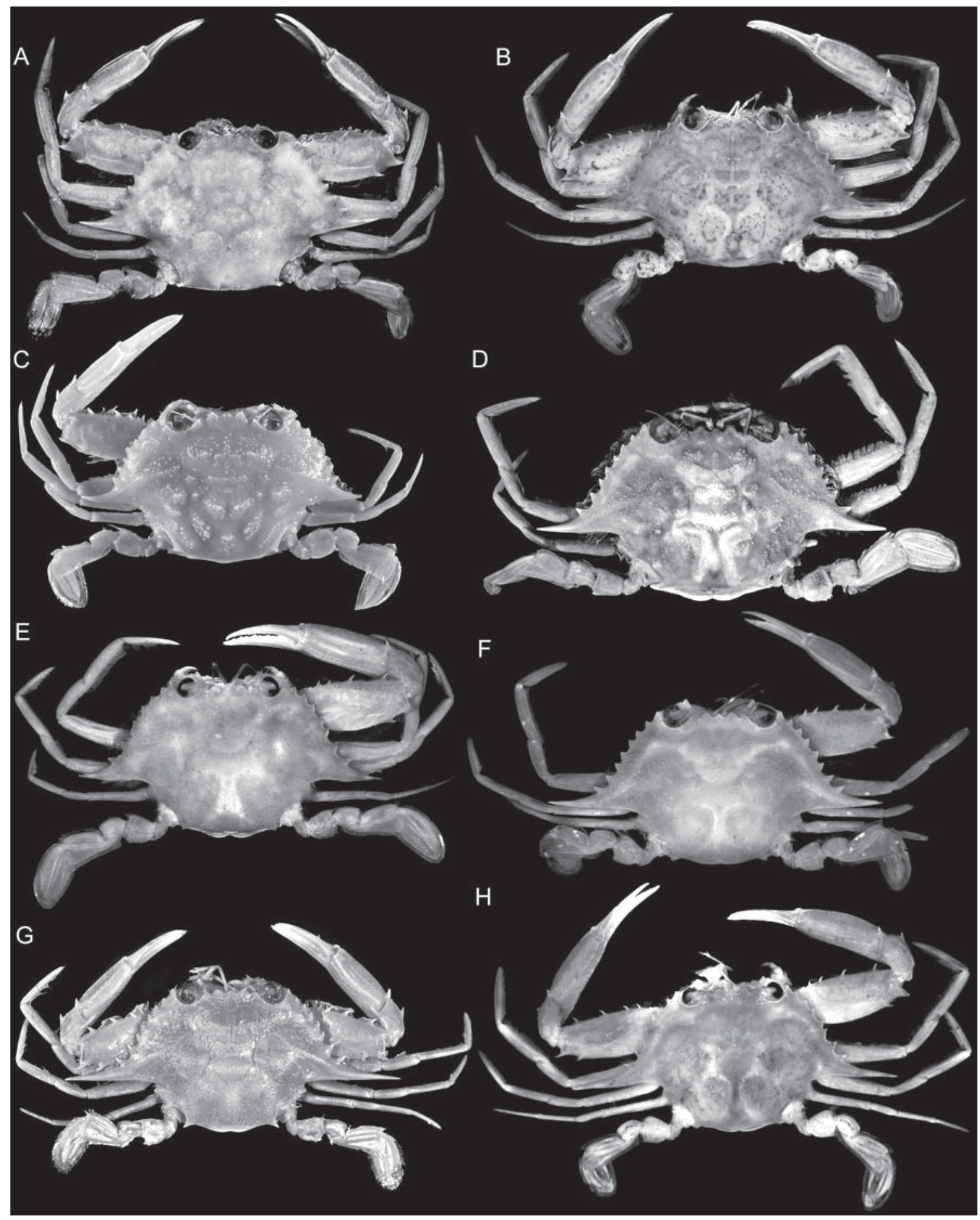

Fig 5. Overall habitus: A — Xiphonectes pseudohastatoides (Yang et Tang, 2006), O' (36.8 $\times 18.7 \mathrm{~mm}$ ) (ZRC 1994.10.3), Taiwan; B — X. pseudohastatoides, $O^{7}(36.8 \times 18.5 \mathrm{~mm})$ (ZRC 2019.1727), Taiwan; C $-X$. arabicus (Nobili, 1905), paralectotype o $(24.4 \times 13.0 \mathrm{~mm})$ (MNHN-IU-2014-4048 = MNHN B.5927), United Arab Emirates (photograph T. Naruse); D - X. unidens (Laurie, 1906), holotype $0^{7}$ $(24.5 \times 11.5 \mathrm{~mm})\left(\mathrm{NHM}\right.$ 1907.5.22.309), Sri Lanka; E - X. unidens, $O^{7}(29.1 \times 15.7 \mathrm{~mm})\left(\mathrm{ZRC}\right.$ 1992.10347), Thailand; F $-X$. unidens, $O^{7}$ $(26.3 \times 11.6 \mathrm{~mm})\left(\right.$ ZRC 2021.0424), Malaysia; G - X. unidens (holotype of Portunus dayawanensis Chen, 1986), $O^{7}(26.4 \times 11.3 \mathrm{~mm})$ (MBMCAS C00989), China; H $-X$. unidens, $\sigma^{7}(31.2 \times 14.1 \mathrm{~mm})$ (ZRC 2019.1728), Hong Kong.

Рис. 5. Общий вид А - Xiphonectes pseudohastatoides (Yang et Tang, 2006), О (36,8×18,7 мм) (ZRC 1994.10.3), Тайвань; В X. pseudohastatoides, O' (36,8×18,5 мм) (ZRC 2019.1727), Тайвань; C - X. arabicus (Nobili, 1905), паралектотип $+(24,4 \times 13,0$ мм) (MNHN-IU-2014-4048 = MNHN B.5927), Объединенные Арабские Эмираты (фото Т. Нарусэ); D - X. unidens (Laurie, 1906), голотип О (24,5×11,5 мм) (NHM 1907.5.22.309), Шри-Ланка; E — X. unidens, Ơ (29,1×15,7 мм) (ZRC 1992.10347), Таиланд; F X. unidens, O7 (26,3×11,6 мм) (ZRC 2021.0424), Малайзия; G - X. unidens (голотип Portunus dayawanensis Chen, 1986), $0^{7}$ (26,4×11,3 мм) (MBMCAS C00989), Китай; H - X. unidens, О' (31,2×14,1 мм) (ZRC 2019.1728), Гонконг. 

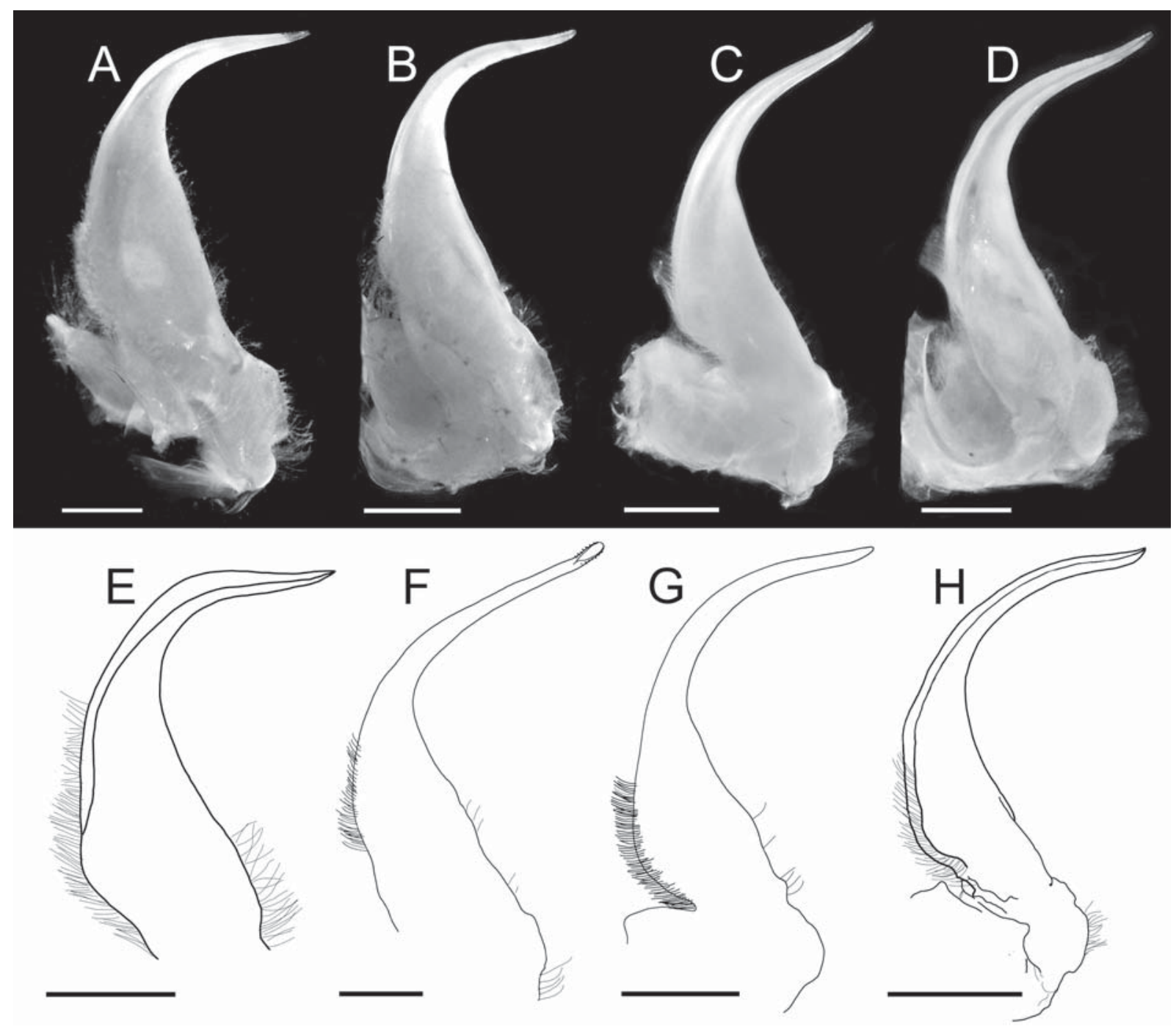

Fig 6. Left G1s: A — Xiphonectes hastatoides (Fabricius, 1798) s.str., O' (40.6×22.4 mm) (ZRC 2000.1396), Malaysia (Penang); B X. vassilyi sp.n., holotype $\sigma^{7}(33.4 \times 16.0 \mathrm{~mm})$ (ZRC 2009.0888a), South Africa; C - X. subtilis sp.n., holotype $\sigma^{7}(35.1 \times 17.3 \mathrm{~mm})($ ZRC 2003.0527), Indonesia; D - X. subtilis sp.n., Oొ (32.0×16.7 mm) (ZRC 1995.629), Taiwan; E $-X$. arabicus (Nobili, 1905), lectotype $\mathrm{O}^{7}$ $(\mathrm{CW}=28 \mathrm{~mm}$ ), United Arab Emirates [Apel, Spiridonov, 1998: fig. 95e]; F — X. pseudohastatoides (Yang et Tang, 2006) $(43.0 \times 21.5$ mm) (ZRC 1997.762), China; G - X. unidens (Laurie, 1906) (30.2×13.3 mm) (ZRC 2000.0934), Thailand; H - X. unidens (holotype of Portunus dayawanensis Chen, 1986), o $O^{\top}(26.4 \times 11.3 \mathrm{~mm})$ (MBMCAS C00989), China [Chen, 1986: fig. 1.6]. Scales $=1.0 \mathrm{~mm}$.

Рис. 6. Левый G1s: A — Xiphonectes hastatoides (Fabricius, 1798) s.str., O’ (40,6×22,4 мм) (ZRC 2000.1396), Малайзия (Пенанг); В - X. vassilyi sp.n., голотип О (33,4×16,0 мм) (ZRC 2009.0888 a), Южная Африка; С - X. subtilis sp.n., голотип О7 (35,1×17,3 мм) (ZRC 2003.0527), Индонезия; D - X. subtilis sp.n., O (32,0×16,7 мм) (ZRC 1995.629), Тайвань; E - X. arabicus (Nobili, 1905), лектотип О7 (CW = 28 мм), Объединенные Арабские Эмираты [Apel, Spiridonov, 1998: pис. 95e]; F - X. pseudohastatoides (Yang et Tang, 2006) (43,0×21,5 мм) (ZRC 1997,762), Китай; G - X. unidens (Laurie, 1906) (30,2×13,3 мм) (ZRC 2000.0934), Таиланд; H X. unidens (голотип Portunus dayawanensis Chen, 1986), О (26,4×11,3 мм) (MBMCAS C00989), Китай [Сhen, 1986: рис. 1.6]. Масштаб 1,0 мм.

teeth (Fig. 3B). Anterolateral margin gently convex (Fig. 2A). Posterior carapace margin appears almost straight in posterior view (Fig. 4B); posteroexternal carapace angle with spine directed obliquely laterally, prominently curves upwards (Figs 3F, 4B). Dactylus of swimming leg without dark spot. G1 tapering, strongly curved at about two-thirds length from basal part; distal portion gently curved upwards (Fig. 6B)

ETYMOLOGY. The species is named after the late Vassily Albertovich Spiridonov, whose many contributions to portunoid systematics have led us to a much better understanding of their classification and diversity.
REMARKS. The figures and description of $X$. hastatoides by Barnard [1950: 158, figs 30e-g] agree well with the present material of $X$. vassilyi sp.n., especially in the structure of the acute and distinctly upturned posteroexternal carapace spine (Fig. 4B); which is a diagnostic feature for this species. Crosnier's [1962] specimens of X. hastatoides from Madagascar probably also belong to $X$. vassilyi sp.n. because he noted that the posteroexternal carapace angle has a prominent spine, and his figure of the G1 [Crosnier, 1962: fig. 117] matches that of $X$. vassilyi sp.n. from South Africa.

DISTRIBUTION. South Africa and Madagascar. 
Xiphonectes subtilis sp.n.

Figs 2B, C, 3C, D, 3G, H, 4C, D, 6C, D.

Portunus hastatoides - Stephenson, Campbell, 1959: 101, figs 2D, 3D, pl. 1 fig. 4, pl. 4 figs 4D, 5D; Sakai, 1965: 119, pl. 58, fig. 2; McNeill, 1968: 55; Dai et al., 1986: 196, pl. 26(3), fig. 114(2); Chen, 1991: 356, fig. 356; Dai, Yang, 1991: 212 (key) 216, pl. 26 (3), fig. 114 (2); Moosa, 1995: 522; Huang, Yu, 1997: 68 (part); Lai et al., 1997: 229, fig. 3E; Spiridonov, 1999: 76; Yang, Tang, 2006: 695, fig. 3; Wong et al., 2010: 669, figs 1A-D, 2A, 2B, 3C, 3D; Yang et al., 2012: 139-143, fig. 52, pl. 9: 2. [not P. hastatoides Fabricius, 1798]

Amphitrite hastatoides — Stimpson, 1858: 38; 1907: 78.

Neptunus (Amphitrite) hastatoides - De Haan, 1833: pl. 1 fig. $3 ; 1835: 39$.

Neptunus (Hellenus) hastatoides - Yokoya, 1933: 178; Sakai, 1934: 303; 1935: 130, pl. 36, fig. 1; 1939: 391, pl. 47 fig. 1.

Portunus (Amphitrite) hastatoides - Maki, Tsuchiya, 1923 138, pl. 11(5).

Portunus (Xiphonectes) hastatoides — Sakai, 1976: 344, pl. 119 fig. 2.

MATERIAL EXAMINED. Holotype, $\mathrm{O}^{7}(35.1 \times 17.3 \mathrm{~mm})(\mathrm{ZRC}$ 2003.0527), stn. EA-TT06, Indonesia, Anambas, Teluk Tarempa, coll. Anambas Expedition, 14.03.2002. Paratype: 1 우 $(34.8 \times 17.2$ $\mathrm{mm}$ ) (ZRC 2021.0373), same data as holotype. Others - Borneo $3 \sigma^{7} \sigma^{7}(28.3 \times 12.6 \mathrm{~mm} ; 28.3 \times 12.8 \mathrm{~mm} ; 31.2 \times 13.2 \mathrm{~mm}), 1$ juv. $(20.4 \times 13.5 \mathrm{~mm})(\mathrm{RUMF}), 1 \mathrm{O}^{7}(28.8 \times 14.4 \mathrm{~mm}$, left anterolatera tooth broken) (ZRC 2021.0367), Sepilok Laut Troll, eastern Sabah, Malaysia, coll. T. Naruse, 17.11.2015; Peninsular Malaysia: $10^{7}$ (ZRC 1965.10.21.21-23), in fish trap, Penang, 4-5 fms, coll M.W.F. Tweedie, 06.1934; $10^{7}$, 2 오 (ZRC 2021.0434), Johor Pontian, coll. P.K.L. Ng, 02.1993; Singapore: $10^{7}, 1+1$ juv. $0^{7}$ (ZRC 2021.0433), southeast of Pulau Ubin, in sandy mud, 5-6 m, coll. R. von Cosel \& S.K. Tan, 21.11.2008; 2 우 (ZRC 1965 10.21.12-13), Sultan Shoals, coll. A.M., 07.1934; 1 juv. O $^{7}$ (ZRC 2013.1466), on fine shell gravel with sponges, off Pulau Semakau, north side, 13-15 fms, coll. 3.01.1969; 1 juv. O' $^{7}$ (ZRC 1991.9465), Pulau Semakau, south side, sledge E4, coll. 14.03.1989; 1 juv. ${ }^{7}$ $(19.0 \times 8.7 \mathrm{~mm}), 1$ juv. 9 (ZRC 1993.134-135), Pulau Semakau, coll. P.K.L. Ng, 1991; 1 juv. O7 (ZRC 1993.143), Pulau Bukom, coll. T.L. Koh, 02.1992; $1 \mathrm{O}^{\top}$ (ZRC 1985.1608), Bedok, $15 \mathrm{~m}$, coll P.K.L. Ng, 27.04.1982; 2 juv. ${ }^{7}$ (ZRC 1990.8406-8407), station 6, sledge 2, Kallang Basin, coll. 23.02.1989; 1 juv. (ZRC 1993.7457), Singapore, coll. 13.05.1986; 1 juv. O' (ZRC 7453), stn D8, Singapore, coll. 25.04.1986; 1 juv. $0^{7}$ (ZRC 1993.7444), Southern Islands, coll. D. Lane, 1992; 1 juv.+ (ZRC 1965.10.21.11), Telok Siang, east coast of Johor, coll. M.W.F. Tweedie, 28.08.1933; $10^{7}, 1$ ㅇ (ZRC 2000.1376), off Singapore, coll. 1960s; Thailand: 1 damaged juv. $0^{7}$ (ZRC 2000.0020), Chonburi Province, Siracha port, coll. P.K.L. Ng, 11.1999; Indonesia: $4 \sigma^{7} \sigma^{7}(36.5 \times 18.8 \mathrm{~mm}$; $37.3 \times 18.0 \mathrm{~mm} ; 30.4 \times 15.1 \mathrm{~mm} ; 32.5 \times 15.2 \mathrm{~mm}), 2$ 우 $(32.5 \times 15.5$ $\mathrm{mm} ; 35.1 \times 17.9 \mathrm{~mm}), 1$ broken,+ 2 ovig. . + $9(33.8 \times 15.6 \mathrm{~mm} ; 32.0 \times$ $14.8 \mathrm{~mm}$ ) (ZRC 2003.0528), stn. EA-TT08, Indonesia, Natunas, westcoast of Pulau Bunguran, coll. Anambas Expedition, 18.03. 2002; Australia: $3 \sigma^{7} \sigma^{7}(41.7 \times 20.0 \mathrm{~mm}, 46.7 \times 23.5 \mathrm{~mm} ; 38.0 \times 18.3$ $\mathrm{mm}), 2$ 우우 $(45.0 \times 22.1 \mathrm{~mm} ; 40.2 \times 20.2 \mathrm{~mm})($ ZRC 2012.0005$)$, Queensland, Morton Bay; $50^{7} \sigma^{7}$ (largest $36.1 \times 17.3 \mathrm{~mm}$ ), 1 우 (QM 2197-2203), Queensland, Gulf of Carpenteria, southeast of Wellesley Islands, trawled (Gulf prawn survey), coll. I. Kirkegeerd, 13.11.1964; 1 (9 $(36.0 \times 15.5 \mathrm{~mm})($ ZRC 1965.10.21.25), Linderman I., 08.1935; Mainland China: $10^{7}(36.9 \times 16.7 \mathrm{~mm}), 1$ juv. ${ }^{7}$ (ZRC 1999.0219.2), China, Tungdu market, Fujian Province, coll. Y. Ca \& N. K. Ng, 18.11.1998; Hong Kong: $10^{7}, 3$ 우 (ZRC 2019.1719), station S2, off Po Toi Island, University of Hong Kong Trawling Surveys, coll. K. Wong, 6.08.2018; $20^{7} \sigma^{7}$, 2 우 (ZRC 2019.1726), stn S2, south of Po Tai, University of Hong Kong Trawling Surveys, coll. K. Wong, 19.07.2018; Taiwan: $10^{7}(32.0 \times 16.7 \mathrm{~mm})$ 4 오 $(32.6 \times 16 \mathrm{~mm} ; 30.2 \times 15.6 \mathrm{~mm} ; 29.6 \times 14.8 \mathrm{~mm} ; 27.6 \times 13.8$ mm) (ZRC 1995.629), Mi-Tou (southwestern Taiwan), trawled at $20 \mathrm{~m}, 08.1994-07.1995 ; 10^{7}(26.4 \times 13.4 \mathrm{~mm}), 494$ (largest $27.2 \times 14.1 \mathrm{~mm}$ ) (ZRC 1995.5.20), Jong-Yun (southwestern coast of Taiwan), trawled at $10 \mathrm{~m}, 08.1994-07.1995 ; 2 \sigma^{7} \mathrm{O}^{7}(30.8 \times 15.7$ $\mathrm{mm} ; 28.4 \times 14.4 \mathrm{~mm}), 2$ 우 $(33.0 \times 16.5 \mathrm{~mm} ; 26.7 \times 12.8 \mathrm{~mm})($ ZRC 2021.0368), Pingtung county, Donggang fish market, 4.06.1992.

DIAGNOSIS. Frontal margin with 4 median teeth, median pair short, half as long as lateral teeth, notch between median pair shallow (Fig. 3C, D). Anterolateral margin gently convex to almost straight (Fig. 2B, C). Posterior carapace margin appears straight to sinuous in posterior view (Fig. 4C, D); posteroexternal carapace angle with spine directed obliquely laterally to laterally, clearly curves upwards (Figs 3G, H, 4C, D). Dactylus of swimming leg sometimes with dark spot, occasionally not visible. G1 tapering, gently curved anterolaterally at middle of length, relatively more slender (Fig. 6C, D).

ETYMOLOGY. This species is the closest to X. hastatoides s.str., and has an overlapping distribution in Southeast Asia. The differences between the two species are relatively small but consistent; consequently, the new species is named subtilis meaning "slightly". Gender masculine.

REMARKS. The present series of $X$. subtilis sp.n. belong to approximately two groups. One group of specimens, all from Taiwan, do not have a dark spot on their swimming dactylus, the spine at the posteroexternal carapace angle is directed laterally (Fig. $3 \mathrm{H}$ ) and the anterolateral margin (from the external orbital tooth to the base of the last tooth) is almost straight (Fig. 2C). The second group, which occurs from Hong Kong to Southeast Asia and Australia, usually have some indication of a dark spot on their swimming dactylus but this is often not visible, the spine at the posteroexternal carapace angle is directed laterally and gently curves upwards (Fig. 3G) and the anterolateral margin (from the external orbital tooth to the base of the last tooth) is gently convex (Fig. 2B). At present, however, these characters are not reliable, and the two groups cannot be distinguished as separate taxa with confidence. The form of their frontal median teeth and G1s are identical (Figs 3C, D, 6C, D). The problem with relying on the dark spot on the dactylus of the swimming leg is that there appears to be some variation, even for fresh specimens. Wong et al. [2010] had reported that all the " $X$. hastatoides" specimens they examined from Taiwan and Hong Kong have no dark spot on the dactylus of the swimming leg. In one lot (ZRC 2019.1726) from Hong Kong, however, one pair has a visibly dark coloured spot on the dactylus of the swimming leg while the other two has no almost no trace of any dark pigmentation. All four specimens are about the same size.

Specimens from mainland China (ZRC 1999.0219) have a straighter posterior margin in posterior view, resembling the condition in $X$. vassilyi sp.n. (Fig. 4B), rather than the more sinuous condition in typical $X$. subtilis sp.n. (Fig. 4C, D). They are nevertheless, clearly $X$. subtilis sp.n., as the rest of their characters are of this species. Yang and Tang [2006] compared $X$. pseudohastatoides (as a Portunus) to specimens of " $P$. hastatoides" from the South China Sea which are deposited in the Beijing Natural History Museum. Based on the figure by the authors [Yang, Tang, 2006: fig. 3], their " $P$. hastatoides" is considered to be $X$. subtilis sp.n., which also agrees with the known range.

The material referred to " $N$. (A.) hastatoides" by De Haan $[1833,1835]$ from Japan should be X. subtilis sp.n., at least from the figures and description. The same is probably true for material of Stimpson [1858, 1907] from Japan. Japanese specimens which have been referred to " $P$. hastatoides" also probably belong to $X$. subtilis sp.n. The figures in Sakai [1939: pl. 47, fig. 1; 1976: pl. 119, fig. 2] agree with $X$. subtilis sp.n. as defined here (see also Sakai [1935, 1965]; Yokoya [1933]), with the dark spot on the dactylus of the swimming leg not distinct. 
The present collection has five specimens from Queensland, Australia (ZRC 2012.0005) with no spot on the dactylus of swimming leg. The absence of a dark spot on the dactylus of swimming leg might be a species variation or possibly the pigmentation has faded with preservation, but this can only be confirmed after the collection of fresh specimens.

DISTRIBUTION. South China Sea to Singapore, mainland China, Hong Kong, Taiwan, Japan, Peninsular Malaysia (including Penang in Indian Ocean), Sabah, Singapore, eastern Thailand, Indonesia to northern Australia.

\section{Xiphonectes arabicus (Nobili, 1905) Figs 5C, 6F.}

Neptunus (Hellenus) arabicus Nobili, 1905: 163; 1906a: 115, pl. 5 figs 22-22a; 1906b: 190 (key), 191; Stephensen, 1946: 121, figs $26 \mathrm{~A}-\mathrm{C}$.

Neptunus (Hellenus) andersoni - Alcock, 1899: 39; Stephensen, 1946: 122. [not $N$. (H.) andersoni De Man, 1887].

Lupa arabica - Laurie, 1915: 411 (list).

Portunus acerbiterminalis Stephenson, Rees, 1967a: 14, fig. 1 pl. 1B; 1967b: 287; Stephenson, 1972b: 15 (key), 38 (part: records from Saudi Arabia and East Africa).

Portunus arabicus - Stephenson, 1976: 15; Apel, Spiridonov, 1998: 281, figs 95, 98, 99, 106.

Not Portunus acerbiterminalis — Stephenson, 1972a: 134; 1972b: 38 (part: record from India). [= P. hastatoides Fabricius, 1798].

Portunus (Xiphonectes) arabicus - Ng et al., 2008: 152. Naderloo, 2017: 201 fig. 20.22c, 20.36.

MATERIAL EXAMINED. Paralectotypes: $1+(24.4 \times 13.0 \mathrm{~mm})$, 1 juv. $+(23.6 \times 11.8 \mathrm{~mm})(\mathrm{MNHN}-\mathrm{IU}-2014-4048=\mathrm{MNHN}$ B.5927), 1 ovig. $9(23.3 \times 12.3 \mathrm{~mm})(\mathrm{MNHN}-\mathrm{IU}-2008-12826=\mathrm{MNHN}$ B.5926), 1 \% $(18.2 \times 9.3 \mathrm{~mm})(\mathrm{MNHN}-\mathrm{IU}-2014-4050=\mathrm{MNHN}$ B.5928), United Arab Emirates, off the coast of Abu Dhabi (BP Stn. XLVII), $25^{\circ} 00^{\prime} \mathrm{N} 55^{\circ} 00^{\prime} \mathrm{E}, 1901$, coll. J. Bonnier \& Ch. Perez.

DIAGNOSIS. Carapace pubescent, with conspicuously elevated granular regions, median post-cardiac region with distinct tubercles (Fig. 5C). Anterolateral margin with 9 teeth (Fig. 5A). Frontal margin with 4 teeth, median pair smaller, less prominent than submedian pair (Fig. 5C). Posteroexternal carapace angle forming obtuse or right angle, without spine; posterior carapace border appears convex from dorsal view (Fig. 5C). G1 curved, tapering with pointed tip slightly curved upwards (Fig. 6F).

REMARKS. Xiphonectes arabicus is distinguished from $X$. hastatoides s.lat. by the relative coarser granulation of the carapace (vs granules small and rounded to indistinct at times) and the obtuse or right angled posteroexternal carapace angle which does not have spine (vs angle always forming a sharp right angle with a spine in $X$. hastatoides s.lat.).

DISTRIBUTION. From the north-east coast of Somalia, the Gulf of Aden, southern Red Sea and Socotra to the Arabian Gulf [Apel, Spiridonov, 1998].

\section{Xiphonectes pseudohastatoides (Yang et Tang, 2006)} Figs 5A, B, 6F.

Portunus pseudohastatoides Yang et Tang, 2006: 691, figs 1, 2; Wong et al., 2010: 676, figs 1E-N, 2E, F. 152

Portunus (Xiphonectes) pseudohastatoides - Ng et al., 2008:

Portunus hastatoides — Yu, 1979: 48, fig. 5; Huang, Yu, 1997: 68 (part.). [not P. hastatoides Fabricius, 1798]

Xiphonectes pseudohastatoides — Koch et al., 2015: 643, figs 1,2 .

MATERIAL EXAMINED. Taiwan: $5 \sigma^{7} \sigma^{7}(36.8 \times 18.7 \mathrm{~mm}$, $35.0 \times 18.7 \mathrm{~mm}, 36.2 \times 18.3 \mathrm{~mm}, 35.7 \times 18.1 \mathrm{~mm}, 36.2 \times 19.5 \mathrm{~mm})$
(ZRC 2021.0366), Taichung (northwestern coast), trawled at $20 \mathrm{~m}$, coll. 3.10.1994; $2 \sigma^{7} \sigma^{\top}$ (larger $\left.32.6 \times 16.6 \mathrm{~mm}\right), 2$ 우 $(35.0 \times 17.2$ $\mathrm{mm} ; 29.7 \times 14.9 \mathrm{~mm}), 1$ ovig. $9(32.0 \times 15.8 \mathrm{~mm})($ ZRC 2021.0365$)$, Bort-Zae-Liau (northwestern coast), trawled at $10 \mathrm{~m}$, coll. 21.07 . $1995 ; 3 \sigma^{7} \sigma^{7}(38.6 \times 19.5 \mathrm{~mm}, 37.4 \times 18.2 \mathrm{~mm}, 33.5 \times 17.0 \mathrm{~mm}), 2$ 우 $(34.0 \times 16.8 \mathrm{~mm} ; 32.4 \times 16.0 \mathrm{~mm})($ ZRC 2021.0370), Ma-Sha-Gou (western coast), trawled at $70 \mathrm{~m}$, coll. $2008.1994 ; 30^{7} \sigma^{7}, 2$ ovig. .90 $(36.5 \times 18.0 \mathrm{~mm}, 32.1 \times 15.1 \mathrm{~mm})($ ZRC 2021.0369), Ma-Sha-Gou (western coast), trawled at $70 \mathrm{~m}$, coll. 14.09.1994; $6 \sigma^{\top} \sigma^{\top}, 2$. (ZRC 2021.0423), Dasi, Ilan Province (northern coast), coll. T.-Y.

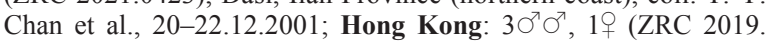
1727), station S3, south of Lantau Island, University of Hong Kong Trawling Surveys, coll. K. Wong, 6.08.2018; Macau: $1 \sigma^{7}(43.0 \times$ $21.5 \mathrm{~mm}$ ) (ZRC 1997.0762), near Macau, coll. Hong Kong Chinese University staff, 1996; Vietnam: $10^{\top}(39.4 \times 19.2 \mathrm{~mm})(Z R C$ 2021.0376), Nam Dinh Province, from fishermen near Xuan Thuy National Park, 7.08.2007; Peninsular Malaysia: $1 \sigma^{7}(28.1 \times 14.3$ mm) (ZRC 2021.0371), Johor, Pontian, coll. P.K.L. Ng, 02.1993; $1 \sigma^{7}$ (ZRC 2021.0377), Johor, Pontian, coll. P.K.L. Ng, 02.1993; $3 \sigma^{7} \sigma^{7}(27.9 \times 12.5 \mathrm{~mm}, 24.2 \times 11.0 \mathrm{~mm}, 26.0 \times 12.3 \mathrm{~mm}), 2$ 우 $(27.2 \times$ $12.6 \mathrm{~mm}, 27.5 \times 12.0 \mathrm{~mm}), 2$ juv. $\sigma^{7} \sigma^{\top}$ (ZRC 1965.10.21.14-20), Selangor, Morib; Singapore: $1 \sigma^{7}$ (ZRC 1984.5616), off Bedok, coll. P.K.L. Ng, 18.11.1981; $2 \sigma^{\top} \sigma^{\top}$ (damaged), $4+9$ (1 damaged) (ZRC 1985.890-895), on sand with shell and gravel, off SiglapBedok, 5 fms, coll. D.S. Johnson, 4.04.1952; 1 juv.+ (ZRC 1990. 8369), stn 4, Kallang Basin, coll. 23.02.1989; 10', 1우 (ZRC 2000.1263 ), off Bedok, $1^{\circ} 18.34^{\prime} \mathrm{N} 103^{\circ} 56.69^{\prime} \mathrm{E}, 5-10 \mathrm{~m}$, coll. D.G.B. Chia et al., 19.08.1994.

DIAGNOSIS. Frontal margin with 4 teeth. Median teeth as long as submedian pair, separated by a V-shape notch, notch depth is about half length of median teeth (Fig. 5A, B). Posteroexternal carapace angle with spine directed obliquely laterally, gently curved upwards (Fig. 5A, B). Dactylus of swimming leg with dark spot (Fig. 5A, B). G1 stout; neck slender, tapering; tip with spoon-shaped opening, surrounded by about 10 spinules directed slightly backwards on each side of opening (Fig. 6F).

REMARKS. All specimens used in this study have dark spot on dactylus of swimming leg. Wong et al. (2010) noted that the dark spot is inconsistent in their material, with the pigment absent from some specimens. This may be due to pigment leaching during preservation and/or they may have two species including some specimens of $X$. subtilis sp.n.

Yang and Tang [2006] compared X. pseudohastatoides with the " $X$. hastatoides" figured in Crosnier [1962: figs 96, 109, 122, 123] and Stephenson \& Campbell [1959: figs 2D, 3D, pl.1, fig. 4, pl. 4, fig. D]. As discussed earlier, these old records of " $X$. hastatoides" belong to two different species, $X$. vassilyi sp.n. [in Crosnier, 1962] and X. subtilis sp.n. [in Stephenson et Campbell, 1959]. According to Yang \& Tang [2006], the posterolateral margin is convex in X. pseudohastatoides but concave in $X$. hastatoides. This margin howev$\mathrm{er}$, is actually convex in our specimens of $X$. hastatoides s. str. (Fig. 1A), X. vassilyi sp.n. (Fig. 2A), and $X$. subtilis sp.n. (Fig. 2C, D). Wong et al. [2010] keyed out the differences between $X$. pseudohastatoides and $X$. subtilis sp.n. (as " $P$. hastatoides"), noting that the former species has the median frontal teeth as long as the laterals (vs median teeth shorter than laterals) and with a slender G1 that has an opening which is spatuliform (Fig. 6F) (vs proportionately less slender with a tapering tip G1). The frontal median teeth character is correct for $X$. vassilyi sp.n. and $X$. subtilis sp.n. (Fig. 3B-D), but not $X$. hastatoides s.str. (Fig. 3A). Therefore, the G1 structure remains the most reliable character to distinguish $X$. pseudohastatoides from 6 species in the $X$. hastatoides species group.

DISTRIBUTION. Guangxi Province, Guangdong Province (South China: type locality), Hong Kong, Macau, west 


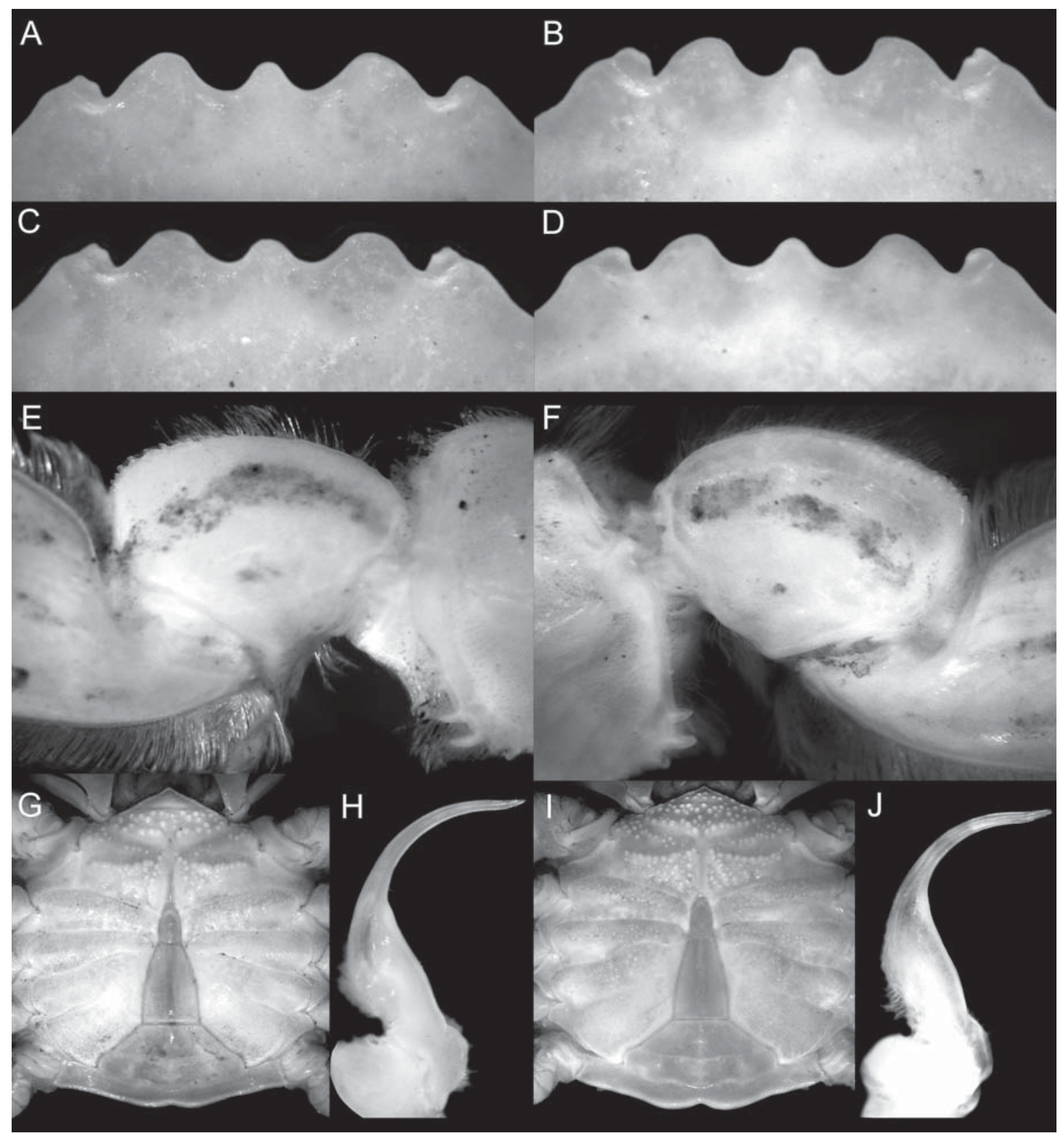

Fig. 7. Xiphonectes unidens (Laurie, 1906). A $-\mathrm{O}^{7}(25.5 \times 11.7 \mathrm{~mm})$ (ZRC 1992.10347), Thailand; B $-\mathrm{O}^{7}(29.3 \times 14.8 \mathrm{~mm})(\mathrm{ZRC}$ 1992.10347), Thailand; C — O (23.6×11.0 mm) (ZRC 1992.10347), Thailand; D — $+(24.6 \times 12.0 \mathrm{~mm})($ ZRC 1992.10347), Thailand; E$\mathrm{H}-$ X. trilobatus (Stephenson, 1972a), O $\sigma^{7}(31.2 \times 14.1 \mathrm{~mm})$ (ZRC 2019.1728), Hong Kong; I, J $-X$. unidens (Laurie, 1906), $\bigcirc^{7}$ $(29.1 \times 15.7 \mathrm{~mm})($ ZRC 1992.10347), Thailand. A-D — frontal teeth; E — left carpus of swimming leg; F — right carpus of swimming leg; G, I - thoracic sternum and pleon; H, J - right G1 (laterally transposed for comparative purposes).

Рис. 7. Xiphonectes unidens (Laurie, 1906). A — O (25,5×11,7 мм) (ZRC 1992.10347), Таиланд; В — O (29,3×14,8 мм) (ZRC 1992.10347), Таиланд; C — O (23,6×11,0 мм) (ZRC 1992.10347), Таиланд; D — + (24,6×12,0 мм) (ZRC 1992.10347), Таиланд; E-H — $X$. trilobatus (Stephenson, 1972a), O (31,2×14,1 мм) (ZRC 2019.1728), Гонконг; I, J - X. unidens (Laurie, 1906), О O $^{7}(29,1 \times 15,7$ мм) (ZRC 1992.10347), Таиланд. A-D - передние зубцы; Е - карпус левой плавательной ноги; F — карпус правой плавательной ноги; G, I - грудные стерниты и плеон; H, J - правый G1 (установлен боком для сравнения).

coast (Taiwan Strait) and northeastern Taiwan, Vietnam, Peninsular Malaysia and Singapore.

Xiphonectes unidens (Laurie, 1906) Figs 5D-H, 6G, H, 7.

Neptunus (Hellenus) hastatoides var. unidens Laurie, 1906: 414.
Neptunus (Hellenus) tweediei Shen, 1937: 109, figs 6, 8c, 8d. Portunus dayawanensis Chen, 1986: 84, fig. 1; Wong et al., 2010: 674, figs 1E-I, 2C, D.

Portunus trilobatus Stephenson, 1972a: 139, figs 1, 2; Davie, 1992: 488, 495.

Portunus tweediei — Stephenson, 1972b: 14.

Portunus (Xiphonectes) dayawanensis - Ng et al., 2008: 152. Portunus (Xiphonectes) trilobatus - Ng et al., 2008: 152. 
Portunus (Xiphonectes) tweediei - Ng et al., 2008: 153.

MATERIAL EXAMINED. Holotype, $O^{7}(24.5 \times 11.5 \mathrm{~mm}$, chelipeds missing) (NHM 1907.5.22.309), Gulf of Manaar, Sri Lanka, coral reefs, coll. W.A. Herdman. Others - Singapore: $10^{\top}(29.9 \times$ $14.3 \mathrm{~mm}), 1$ 우 $(25.0 \times 12.2 \mathrm{~mm})(\mathrm{NHM} 1937.11 .15 .170-171)$ (paratypes of $P$. tweediei Shen, 1937), Siglap; $10^{7}$ (ZRC 1993.7455), station D11, coll. 15.05.1986; 1우 (ZRC 1990.7321), station 5, Kallang Basin, in dredge, coll. $6.02 .1987 ; 13 \sigma^{7} \sigma^{7}, 2$, 9 , 1 ovig. (ZRC 1965.7.5.45-57), Siglap, coll. M.W.F. Tweedie, 12.1933; $20^{7} O^{7}$ (ZRC 1985.898-899), stn B50, on mud, off Tanjong Rhu, 2 fms, coll. SRFRS, 06.1963; 1 ovig. (ZRC 1985.909-911), station B54, on mud with gorgonians, Samar Laut, 5-8 fms, Singapore, coll. SRFRS, 1960s; $20^{7} 0^{7}$, 5 우우 (damaged) (ZRC 1985.900-906), stn B49, on muddy-sand with Enhalus, off Siglap Obelisk, coll. SRFRS, 06.1963; $10^{7}$ (ZRC 1985.907), station B45, on mud and stone substrate, 1 mile west of Bedok, 6 fms, coll. SRFRS, 06.1963 $10^{7}$ (ZRC 1985.908), Selat Sinki, Singapore, coll. A.G. Searle, 06.1963; Peninsular Malaysia: $2 \sigma^{7} \sigma^{7}$ (larger $\left.26.3 \times 11.6 \mathrm{~mm}\right)(\mathrm{ZRC}$ 2021.0424), Johor, Pontian, coll. P.K.L. Ng, 02.1993; Thailand: $3 O^{7} O^{7}(25.4 \times 11.4 \mathrm{~mm}, 25.9 \times 12.0 \mathrm{~mm}, 27.7 \times 11.9 \mathrm{~mm}), 1$ 우 $(23.2 \times 10.3 \mathrm{~mm})($ ZRC 1999.0796), Songkhla port, coll. H.H. Tan, 27.10.1998; 19 (ZRC 1999.0796), Songkhla port, southern Thailand, coll. H.H. Tan, 27.10.1998; $70^{\top} \sigma^{\top}$, 1 우 $(25.8 \times 11.2 \mathrm{~mm}), 2$ ovig. 우 $(28.0 \times 12.2 \mathrm{~mm}, 22.5 \times 11.0 \mathrm{~mm})($ ZRC 2000.0934), Gulf of Thailand, Chonburi, Si Racha port, $20 \mathrm{~m}$ depth, coll. P.K.L. Ng et al., 22.02.2000; 10', 2 ovig.+우 (ZRC 2021.0425), Si Racha port, Chonburi Province, coll. P.K.L. Ng, 17.03.2005; 2 우 (ZRC 2013.02050), Angsila port, Chonburi Province, coll. S. Panha et al., 3.12.2004; 10', 1 ovig. + (ZRC 1998.1170), Angsila port, Chonburi Province, coll. P.K.L. Ng et al., 29.09.1986; 2 우 (ZRC 2013.02050), Angsila port, Chonburi Province, coll. S. Panha et al., 3.12.2004; $10^{3}, 1$ ovig. + (ZRC 1998.1170), Angsila port, Chonburi Province, coll. P.K.L. Ng et al., 29.09.1986; $110^{7} \sigma^{7}$, 9 우 (ZRC 1992.10347), Pattaya port, from trawlers, coll. P.K.L. Ng et L.B. Holthuis, 25.12.1991; Philippines: $10^{7}, 1$ juv. $0^{7}$ (ZRC 2021.0426), mud substrate, stn S25, Ubajan, Bohol, 21 m, Philippines, $9^{\circ} 41.5^{\prime} \mathrm{N} 123^{\circ} 51.0^{\prime} \mathrm{E}$, coll. PANGLAO 2004 Expedition, 23.06.2004; 1 ㅇ (ZRC 2021.0427), mud substrate, station S25, Ubajan, Bohol, $21 \mathrm{~m}$, Philippines, $9^{\circ} 41.5^{\prime} \mathrm{N} 123^{\circ} 51.0^{\prime} \mathrm{E}$, coll. PANGLAO 2004 Expedition, 23.06.2004; $10^{7}$ (ZRC 2021.0428), station T19, mud substrate, Cortes, Bohol, 10-26 m, Philippines, $9^{\circ} 42.2^{\prime} \mathrm{N} 123^{\circ} 50.8^{\prime} \mathrm{E}$, coll. PANGLAO 2004 Expedition, 20.06.2004; Mainland China: $10^{\top}(26.4 \times 11.3 \mathrm{~mm})$ (holotype of P. dayawanensis Chen, 1986) (MBMCAS C00989), China, Guangdong Province, Daya Wan Bay, Sanmen Island, 24.12.1980. Paratypes: 3 우 $(29.2 \times 14.5 \mathrm{~mm} ; 25.0 \times 11.2 \mathrm{~mm}, 16.8 \times 7.3 \mathrm{~mm})$ (MBMCAS C00990), same data as holotype; Hong Kong: $50^{7} \sigma^{7}$, 2우 (ZRC 2019.1728), stn E3, Tolo Channel, University of Hong Kong Trawling Surveys, coll. K. Wong, 23.07.2018.

DIAGNOSIS. Carapace dorsal surface with rounded granules, surface with low setae or almost glabrous. Regions moderately well defined, gastric, cardiac, lateral, and median postcardiac regions gently elevated, separated by deep grooves (Fig. 5D-H). Frontal margin with 3 blunt triangle teeth. Median tooth smaller, less prominent than 2 lateral teeth (Figs 5D-H, 7A-D). Anterolateral border 9 teeth, last one long, slightly arched posteriorly (Fig. 5D-H). Posteroexternal carapace angle with spine, directed obliquely upwards (Fig. 5D-H). Manus of cheliped with 3 or 4 spines on anterior border, 2 on posterior border. Carpus with 2 spines (Fig. E-H). Merus with 2 spines, 1 at articulation with carpus, 1 at inner distal angle. Posterodistal border of merus of swimming leg serrated, dactylus usually without dark spot (Fig. 7E, F). Male pleonal somite 6 with lateral sides parallel from base to half or two-thirds of length, convergent at distal part (Fig. 7G, I). G1 distinctly becomes narrower after one-third of length from basal part; distal part elongate, extremity with several spines (Figs 6G, H, 7H, J).

REMARKS. Neptunus $(H$.) hastatoides unidens was originally described from one male specimen collected from the
Gulf of Manaar in Sri Lanka. The type specimen is missing both chelipeds, and Laurie had difficulty in deciding its identity, remarking that it may just be a variant of $X$. hastatoides (as a N. (Hellenus)). Stephenson \& Campbell [1959: $101]$ treated the $N$. (H.) hastatoides unidens of Laurie [1906], as a junior subjective synonym of $P$. $(X$.) hastatoides, but did not elaborate. Indeed, most revisions do not even refer to Laurie's taxon as he did not figure it and the description was too brief to use. The present authors re-examined the type specimen of $N$. $(H)$.$h . unidens and confirmed that it is not$ congeneric with $X$. hastatoides s.str. The male holotype is distinct in having only three frontal teeth (Fig. 5D) (vs four frontal teeth in $X$. hastatoides s.str.), no dark spot on the dactylus of the swimming legs (vs usually with dark spot in $X$. hastatoides s.str.), and it has a more slender and elongate G1 (vs relatively shorter and stouter in $X$. hastatoides s.str.). Thus, $X$. unidens is a valid species. In fact, the species of Laurie is almost identical with what Shen [1937)] described as $N$. (H.) tweediei from Singapore. This species was described as follows: "front cut into three teeth, the median one is smaller than the laterals; the last anterolateral tooth is long, directed slightly postero-laterally; and mostly similar to $N$. (H.) hastatoides Fabricius, 1798" [Shen, 1937]. Shen noted that $N$. (H.) tweediei is distinguished by the: a) front cut into three teeth (vs four teeth in $N$. (H.) hastatoides), b) dactylus of swimming legs without dark spot (vs with dark spot in $N$. (H.) hastatoides), and c) the G1 is more curved (vs less curved in $N$. (H.) hastatoides) [Shen, 1937: 109, fig. $8 \mathrm{c}$ versus fig. $8 \mathrm{~g}]$. Although Shen described the median frontal tooth as smaller than the laterals, his figure [Shen, 1937: fig. 6a] actually shows the median one to be the largest, albeit slightly. The types of $N$. (H.) tweediei were examined, and this is the only difference with the type male of $X$. unidens, which has the median tooth lower (Fig. 5D). Although a specimen with the median tooth largest has not been seen, some specimens examined possessed subequal to the lateral teeth (Fig. 7D), and as a character, these teeth do vary in size (Fig. 7A-C).

Stephenson [1972a] described X. trilobatus (as a Portu$n u s$ ) from from Sumatra, Java, Sulawesi and Luzon (Philippines). He distinguished $X$. trilobatus from $X$. spiniferus, $X$. alcocki and $X$. mariei by their carapace morphology, armature of their cheliped carpus, form of the median frontal tooth and proportions of the male pleon. Inexplicably, he did not compare his new species with the two taxa closest to it: $X$. unidens and $X$. tweediei.

Chen [1986] named $X$. dayawanensis (as a Portunus) from Daya Bay in southern China with three frontal teeth, and she compared her new taxon with $P$. trilobatus, arguing that their carapaces and chelipeds were distinct. Davie [1992: 488, 495], apparently not aware of Chen's [1986] paper, commented that he had numerous specimens $P$. trilobatus from Hong Kong waters, and that earlier records of " $P$. hastatoides" (see Cheung [1990]) from the territory were probably these species, mainly because it only had three frontal teeth. Wong et al. [2010: 678] argued that they had a good series of specimens from Hong Kong and all $P$. trilobatus records of Davie [1992] should be referred to $X$. dayawanensis. Wong et al. [2010: 678], however, noted that they did not have specimens of $X$. trilobatus, and followed Stephenson [1972a] and Chen [1986] in separating the two species.

In distinguishing $X$. trilobatus from $X$. dayawanensis, Chen [1986: 87, 89] observed that the dorsal carapace surface of $X$. trilobatus has a dense fine pubescence (vs gla- 
brous in $X$. dayawanensis), the mesogastric and metagastric regions each has a short ridge (vs without a ridge in $X$. dayawanensis), the mesobranchial region has four granular patches (vs without patches in $X$. dayawanensis), the inner surface of the palm has two rows of setae but no ridges (vs glabrous but with two ridges in $X$. dayawanensis), and the posterodistal margin of the carpus of the swimming leg has small spines (vs absent in $X$. dayawanensis). The problem is that Chen [1986] probably based these carapace and pereiopod differences mainly on the description by Stephenson [1972a: 140] as his figure of the holotype [Stephenson, 1972a: fig. 2] is poor. The types of $X$. dayawanensis were examined and they agree very well with the material we have on hand from Hong Kong. The specimens vary too much in the carapace pubescence to make this a useful character. There is always some pubescence, from sparse to denser, but none are completely smooth. The pattern of small granules on the meso- and metagastric regions varies in strength and density. In some specimens where the granules on the mesogastric region are denser, they form an irregular but discernible ridge, in others, it is not obvious. The same is true for the granules on the mesobranchial region, it is not always easy to see four patches of granules as they vary in size, with the anterior patches rather less distinct. Certainly, the figure of the holotype male in Stephenson [1972a: fig. 2] does not show prominent mesogastric and metagastric ridges and the patches of granules on the mesobranchial region. The inner surface of the palm has two rows of setae (sometimes lower and sparser) and there is actually a low ridge adjacent to these setae in the specimens examined. When the setae are denser, the ridge is not easy to see or feel. As for the presence of "spines" on the posterodistal margin on the carpus of the swimming leg, this does vary. Stephenson [1972a: 140] describes these as "small spines", and in the specimens examined for the present study, it varies from almost unarmed with low granules (Fig. 7F) to distinct spinules which give it a gently serrate appearance (Fig. 7E), even in the same specimen. In all other characters, including the male pleon and G1 structure (cf. Stephenson [1972a: fig. 1]), X. trilobatus cannot be distinguished from $X$. dayawanensis.

Comparing $X$. trilobatus (and $X$. dayawanensis) with $X$. unidens, it is apparent their general carapace features are similar, with the G1 structures (including the types) almost identical (Figs 6G, H, 7H, J). Among the larger specimens compared, there appear to be some differences: the last anterolateral tooth in $X$. unidens is usually shorter with the posterior margin gently sinuous (Fig. 5D, E) (vs tooth proportionately longer with a straighter posterior margin in $X$. trilobatus, Fig. 5G, H), the surface of male thoracic sternites 1 and 2 are usually distinctly granulated (Fig. 7I) (vs smoother with few granules in $X$. trilobatus, Fig. $7 \mathrm{G}$ ), the median part of the posterior margin of male pleonal somite 3 is usually deeply concave (Fig. 7I) (vs gently concave in X. trilobatus, Fig. 7G), the male pleonal somite 6 is relatively more slender (Fig. 7I) (vs relatively broader in X. trilobatus, Fig. 7G), and the distal slender part of the G1 is slightly shorter (Fig. $7 \mathrm{~J}$ ) (vs slightly longer in in $X$. trilobatus, Fig. 7H). None of these differences, however, are consistent, and specimens were examined, even those from one lot, have intermediate characters. The degree granulation on male thoracic sternites 1 and 2 is surprisingly variable. In many specimens of $X$. trilobatus, the area of sternite 2 adjacent to the suture with sternite 3 is lined with low granules (sometimes low and appears almost smooth, e.g., Fig. 7G), with the rest of the surface smooth but sometimes covered with small rounded granules. In typical specimens of $X$. unidens, the surface of male sternites 1 and 2 is covered with more and stronger granules (Fig. 7I). The variability in the observed differences suggests that they cannot be relied on to separate $X$. trilobatus from $X$. unidens.

The variation in characters observed for the series of specimens of the four species discussed above argue for them to be synonymised, i.e., N. (H.) tweediei Shen, 1937, $P$. trilobatus Stephenson, 1972a, and P. dayawanensis Chen, 1986, are junior subjective synonyms of $N$. (H.) $h$. unidens. Interestingly, a label with the two syntypes of $N$. (H.) tweediei states that these specimens are $P$. unidens. Indeed, someone had previously compared the types of both species in the NHM, and realised they were identical, although nothing was published. The synonymising of these taxa is also supported by their known distributions: $P$. unidens was from Sri Lanka, $P$. tweediei from Singapore, $P$. trilobatus was described from Indonesia and Philippines, and $P$. dayawanensis from southern China.

DISTRIBUTION. Sri Lanka (type locality); Singapore; Malaysia; Gulf of Thailand; Sumatra; Java; Sulawesi; Philippines; Sanmen Island, Daya Bay (= Daya Wan), Guangdong, southern China (type locality) and Hong Kong.

\section{Incertae sedis}

The three species $X$. hastatoides s.str., $X$. vassilyi sp.n. and $X$. subtilis sp.n. are similar to each other, and the G1 shape is a very important character to identify them apart. In this present study, the angle of view of G1 when examined or photographed had to be standardised or they will look different. Xiphonectes pseudohastatoides is also superficially similar and without the G1, one is not always confident to distinguish it from the others. The following records are not sufficiently clear to allow us to be certain and are listed here as incertae sedis:

Neptunus hastatoides - A. Milne-Edwards, 1861: 332, 339 (Japan, China and India). The Indian specimens are probably $X$. hastatoides s.str. but the Chinese and Japanese specimens could be either $X$. subtilis sp.n. or $X$. pseudohastatoides.

Many of the reports of " $P$. hastatoides", " $P$. (X.) hastatoides" or "X. hastatoides" from Taiwan based on fishery catches are probably mixed with three species, X. pseudohastatoides, $X$. trilobatus and/or $X$. subtilis sp.n. These would include the reports of Tzeng \& Chen [1992: unpaginated], Hsueh et al. [2006: 287], Hsueh \& Hung [2009: 455] and Wang et al. [2013a: 513, 2013b: 2017: Appendix 1, unpaginated]. Old records of " $N$. hastatoides" or " $P$. hastatoides" from China, Taiwan and Hong Kong by Sato [1936: 1954], Shen [1940: 220], Lin [1949: 19], Chang [1963: 4], Morton \& Morton [1983], Fang [1991: 352], Huang [1994], Jeng et al. [1997: 117, 1998: 122], Ng et al. [2001: 16, 2017: 71] and Chou \& Fang [2005: 641] are probably similarly mixed. Balss [1922: 108] reported "N. (H.) hastatoides" from Japan, Philippines and China, but we cannot be sure if all the material is one species.

Neptunus (Amphitrite) hastatoides — Miers, 1884: 229 (Indian Ocean, Australia and Hong Kong). His specimens from the Indian Ocean ones are probably $X$. hastatoides s.str. but we are less certain about the Pacific material as there are no figures. While Australia probably has $X$. subtilis sp.n., Hong Kong also has $X$. pseudohastatoides.

Portunus hastatoides — Stephenson, 1967: 15 (Southeast Asia); Stephenson, Rees, 1967b: 14; (China, Taiwan, Japan, Philippines, Borneo); Stephenson, 1972a: 136 (part) (Singapore, Indonesia, Philippines, Thailand, Japan]; 
Stephenson, 1975: 178 (Java); Stephenson, 1976: 16 (Philippines). These records by Stephenson are hard to resolve without re-examining his specimens, with most of the East and Southeast Asian records being X. pseudohastatoides or $X$. subtilis sp.n. or $X$. hastatoides s.str. His [Stephenson, 1972a] records from India and Sri Lanka are probably $X$. hastatoides s.str. while his South Africa and Madagascar specimens are probably $X$. vassilyi sp.n.; but those from Southeast and East Asia can be $X$. pseudohastatoides or $X$. subtilis sp.n. or even $X$. hastatoides s.str. as the latter is known from Singapore.

The records of $X$. hastatoides by Hashmi [1964: 453], Guinot [1967: 257], Zarenkov [1969: 14], Basson et al. [1977: 250], Titgen [1982], Spiridonov [1994: 136], Tirmizi \& Kazmi [1996: 21, fig. 9A-F], Apel \& Spiridonov [1998: 293, figs 100, 101, 105, 107], Neumann \& Spiridonov [1999: 20], Apel [2001: 75], Naderloo \& Sari [2007: 343, table 1] and Naderloo [2017: 202, fig. 20.22e, 20.39] from northeastern Indian Ocean (including Pakistan, Persian Gulf and Red Sea) can either be X. hastatoides s.str. or X. vassilyi sp.n. The G1 figured by some of these authors appear more slender than $X$. hastatoides s.str. (Fig. 6A) but it may just be how it was drawn, and the drawings and descriptions suggest that the two median frontal teeth are distinct. Various authors also describe the posteroexternal carapace angle as produced into curved spines. Stephensen [1946: 122] records "N. (H.) hastatoides" from Iranian Gulf and Gulf of Oman, and although he did not figure the species, he did comment noted that the G1s of his material agreed well with the figure of "P. hastatoides" in Shen [1937a: figs 8g-h] from Singapore where $X$. hastatoides s.str. is present. The record of " $P$. (H.) hastatoides" by Nobili [1905: 11] from Zanzibar is probably $X$. vassilyi sp.n., considering the proximity of this location to Madagascar. In any case, all the specimens from the Arabian Sea and northeastern Indian Ocean should be re-examined to confirm the present prognosis and it is possible some contain both species.

\section{Discussion}

The large number of incertae sedis (see above) means the actual identities of many of the old records cannot be confirmed. It is somewhat surprising considering the number of species of Xiphonectes now recognised that the most widespread species, $X$. hastatoides, has not been properly revised.

The importance of the G1 structure in separating the different species is re-emphasised in this study. The differences in proportions and shape are constant, even for small specimens and remains one of the best ways to distinguish the species. The value of the dark spot on the dactylus of the swimming leg as a taxonomic character remains unresolved. The dark spot, when present, remains for long periods when dried or preserved in formalin, but if specimens are preserved wholly in alcohol, it tends to fade faster. That being said, all fresh specimens and almost all preserved specimens of $X$. hastatoides s.str. possess a distinct dark spot. The closely related $X$. vassilyi sp.n., however, does not have this dark spot even when the specimens were fresh and are absent in the type series. Similarly, every specimen of $X$. pseudohastatoides examined here has a dark spot on the dactylus of the swimming leg. In the case of $X$. unidens, almost every specimen never has the dark spot, even when freshly collected, but there is at least one specimen, a female (ZRC 1999.796) from southern Thailand that has it. The situation for $X$. subtilis sp.n. is the most confusing as the presence or absence of dark spot on the dactylus of the swimming leg appears to be most variable, even from one geographical area. For example, in the waters around southern Peninsular Malaysia and Singapore, some specimens have a distinct dark spot (e.g., ZRC 1993.143, ZRC 2021.0433) while others have no trace of it (e.g., ZRC 2021.0434). Almost all the fresh specimens in Taiwan and Hong Kong of $X$. subtilis sp.n. do not have this spot while most of those from Indonesia have a visible spot. Furthermore, the spot is absent in Australian material. Wong et al. [2010: 678] also discussed the value of this character and were uncertain of its value.

One major difficulty with the species recognised here often have overlapping distributions and their external features are similar. Xiphonectes hastatoides s.str. is known for certain from the Indian subcontinent to the eastern Indian Ocean, and reaching into Southeast Asia. It is relatively common in Singapore with records reaching to Cambodia and southern Vietnam. In Singapore and Peninsular Malaysia, X. pseudohastatoides is also present, but appears to be less common. Xiphonectes pseudohastatoides is the most common species in Taiwan, and is also frequently encountered in mainl7and China, Macau and Hong Kong. The only species known thus far from the eastern part of Southeast Asia (southern and eastern Indonesia, Moluccas, Gulf of Thailand) and Australia is X. subtilis sp.n., and is also common in southern China, Hong Kong and Taiwan. Both X. pseudohastatoides and X. subtilis sp.n. are probably also present in Japan. The many undetermined records of " $P$. hastatoides" from the western Indian Ocean present some uncertainties. It is possible that all the western Indian Ocean records are actually $X$. vassilyi sp.n. instead, which is now known only from Madagascar and South Africa.

For $X$. unidens, which has been confused with $X$. hastatoides since its description in 1906, it is here considered to be the senior synonym of $P$. tweediei, $P$. trilobatus and $P$. dayawanensis. This species is known from southern India to Southeast Asia, extending northwards to the Gulf of Thailand, Hong Kong and southern China. In the western Indian Ocean, it appears to be replaced by $X$. arabicus.

IDENTIFICATION KEY TO SPECIES OF $X$. HASTATOIDES SPECIES COMPLEX

1a. Frontal margin with 4 well demarcated teeth, median 2 may have basal parts fused ........................................ 2

1b. Frontal margin with 3 distinct teeth (Figs 5D-H, 7A-D) X. unidens

2a. Carapace with conspicuously elevated granular regions, median post-cardiac with tubercles; posteroexternal carapace angle forming obtuse or right angle, without distinct spine (Fig. 5C) .................................. X. . arabicus 
Table 1. Morphological differences between species previously confused under Portunus hastatoides s.str. Таблица 1. Морфологические различия между видами, ранее смешанными под названием Portunus hastatoides s.str.

\begin{tabular}{|c|c|c|c|}
\hline Character/species & X. hastatoides s.str. & X. vassilyi sp.n. & X. subtilis sp.n. \\
\hline Median frontal teeth & $\begin{array}{c}\text { As long as submedian } \\
\text { teeth, acute; separated by } \\
\text { deep V-shape notch (Fig. } \\
\text { 3A) }\end{array}$ & $\begin{array}{c}\text { Short, half length of } \\
\text { submedian teeth; separated } \\
\text { by shallow V-shape notch } \\
\text { (Fig. 3B) }\end{array}$ & $\begin{array}{c}\text { Short, half length of submedian } \\
\text { teeth; separated by shallow V- } \\
\text { shape notch (Fig. 3C, D) }\end{array}$ \\
\hline $\begin{array}{c}\text { Dark spot on dactylus } \\
\text { of swimming leg }\end{array}$ & $\begin{array}{c}\text { Dark spot even on dried } \\
\text { and old specimens (Fig. 1) }\end{array}$ & $\begin{array}{c}\text { No dark spot present (Fig. } \\
\text { 2A) }\end{array}$ & $\begin{array}{c}\text { With or without dark spot (Fig. } \\
\text { 2B, C) }\end{array}$ \\
\hline $\begin{array}{c}\text { Spine at } \\
\text { posteroexternal } \\
\text { carapace angle }\end{array}$ & $\begin{array}{c}\text { Straight; directed obliquely } \\
\text { laterally, not curving } \\
\text { upwards (Figs 3E, 4A) }\end{array}$ & $\begin{array}{c}\text { Curved, directed obliquely } \\
\text { laterally, prominently curves } \\
\text { upwards (Figs 3F, 4B) }\end{array}$ & $\begin{array}{c}\text { Curved; directed obliquely } \\
\text { laterally, gently curves } \\
\text { upwards (Figs 3G, H, 4C, D) }\end{array}$ \\
\hline $\begin{array}{c}\text { Posterior carapace } \\
\text { margin in posterior } \\
\text { view }\end{array}$ & $\begin{array}{c}\text { Straight (Fig. 4A) } \\
\text { Relatively straight (Fig. 4B) }\end{array}$ & $\begin{array}{c}\text { Straight or sinuous (Fig. 4C, } \\
\text { D) }\end{array}$ \\
\hline \multicolumn{2}{|c|}{$\begin{array}{c}\text { Relatively stout; sharply } \\
\text { Gent two-thirds length from } \\
\text { basal part; distal part } \\
\text { almost straight (Fig. 6A) }\end{array}$} & $\begin{array}{c}\text { Relatively slender; sharply } \\
\text { bent two-thirds length from } \\
\text { basal part; distal part gently } \\
\text { curved upwards (Fig. 6B) }\end{array}$ & $\begin{array}{c}\text { Relatively slender; gently } \\
\text { curved medially; distal part } \\
\text { gently curved upwards (Fig. } \\
\text { 6C, D) }\end{array}$ \\
\hline
\end{tabular}

2b. Carapace with granular regions, without tubercles; posteroexternal carapace angle with prominent acute angle or spine

3a. G1 with slender neck, distal portion rounded to spoonshaped opening (Fig. 6F) ............ X. pseudohastatoides

3b. G1 stout, tapering to relatively sharp tip ...................... 4

4a. Median frontal teeth as long as submedian teeth, acute; separated by deep V-shape notch (Figs 1A, 3A); spine at posteroexternal carapace angle straight, not prominently curving upwards (Fig. 4A); G1 stout, curving at about $90^{\circ}$, tip directed laterally .................. . hastatoides $\mathrm{s} . \mathrm{str}$.

4b. Median frontal teeth short, half length of submedian teeth; separated by shallow V-shape notch (Figs 3B-D); spine at posteroexternal carapace angle curving upwards (Fig. 4B, C); G1 more slender, gently curving with tip directed obliquely upwards

5a. Spine at posteroexternal carapace angle prominently curving upwards (Fig. 4B); G1 sharply bent two-thirds length from basal part (Fig. 6B); never with dark spot on dactylus of swimming leg .............................. . vassilyi sp.n.

$5 \mathrm{~b}$. Spine at posteroexternal carapace angle gently curves upwards (e.g., Fig. 4C, D); G1 gently curved medially (Fig. 6C, D); dark spot on dactylus of swimming leg variable. X. subtilis sp.n.

Acknowledgements. Thanks are due to many colleagues who have loaned us and/or given specimens for this study, notably the late Chen Huilian (MBMCAS), Paul Clark (NHM), Peter Davie (QM), Chan Tin-Yam (National Taiwan Ocean University, Keelung, Taiwan) and Sean Fennessy (Oceanographic Research Institute, Durban). We also thank Tohru Naruse (University of the Ryukyus) for photographs of the paralectotypes of $X$. arabicus, and to Ng Ngan Kee (National University of Singapore) and Paula MartinLefevre (MNHN) for help with checking and measuring them. The second author is grateful to Neil Bruce and Torben Wolff (ZMUC) for hosting him during his visit there to examine the types of Fabricius. We are most grateful to Paul Clark for his many valuable suggestions which have improved the paper.

\section{References}

Alcock A. 1899. Materials for a carcinological fauna of India. No. 4. The Brachyura Cyclometopa. Part II. A revision of the Cyclometopa with an account of the families Portunidae, Cancridae and Corystidae // Journal of the Asiatic Society of Bengal. Vol.68. P.1-104.

Apel M. 2001. Taxonomie und Zoogeographie der Brachyura, Paguridea und Porcellanidae (Crustacea: Decapoda) des PersischArabischen Golfes. Frankfurt am Main, Germany, Johann Wolfgang Goethe Universität, Biologie und Informatik. Doctoral dissertation. $260 \mathrm{~S}$.

Apel M., Spiridonov V.A. 1998. Taxonomy and zoogeography of the portunid crabs (Crustacea: Decapoda: Brachyura: Portunidae) of the Arabian Gulf and adjacent waters // Fauna of Saudi Arabia. Vol.17. P.159-331.

Balss H. 1922. Ostasiatische Decapoden, IV. Die Brachyrhynchen (Cancridea) // Archiv für Naturgeschichte. Bd.88A. H.11. S.94165. Pls.1, 2.

Barnard K.H. 1950. Descriptive catalogue of South African decapod Crustacea (crabs and shrimps) // Annals of the South African Museum. Vol.38. P.1-837.

Basson P.W., Burchard J.E., Hardy J.T., Price A.R.G. 1977. Biotopes of the Western Arabian Gulf: Marine life and environments of Saudi Arabia. Dhahran: ARAMCO, Department of Loss Prevention and Environmental Affairs. 289 p.

Bhadra S. 1995. Portunidae: Decapoda: Crustacea // Hugli Matla Estuary, West Bengal, Estuarine Ecosystem Series. Kolkata: Zoological Survey of India. Vol.2. P.249-262.

Bhadra S. 1998. Crustacea: Decapoda: Grapsidae // Fauna of West Bengal, State Fauna Series 3, Kolkata: Zoological Survey of India. Vol.10. P.405-415.

Chang C.M. 1963. A check-list of Taiwan crabs with descriptions of 19 new records // Biological Bulletin of the Tunghai University. Vol.14. P.1-23.

Chen H.L. 1986. On two new species of the genus Portunus (Crustacea: Brachyura) from the coast of Guangdong, China // Oceanologia et Limnologia Sinica. Vol.17. No.1. P.84-90.

Chen Y. 1991. [Brachyrhyncha] // Wei C., Chen Y. (eds.). Fauna of Zhejiang. Crustacea. Zhejiang, China: Zhejiang Science and Technology Publication House. P.349-443 [in Chinese].

Cheung S.G. 1990. The distribution and population structure of Portunidae (Crustacea: Decapoda) in Tolo Harbour, Tolo Channel and Mirs Bay, Hong Kong // Morton B. (ed.). Proceedings of the Second International Marine Biological Work- 
shop: The Marine Flora and Fauna of Hong Kong and Southern China, 1986. Hong Kong: Hong Kong University Press. P.935-941.

Chhapgar B.F. 1969. More additions to the crab fauna of Bombay state // Journal of the Bombay Natural History Society. Vol.65. No.3. P.608-617.

Chopra B.N. 1935. Further notes on Crustacea Decapoda in the Indian Museum. VIII. On the Decapod Crustacea collected by the Bengal Pilot Service off the mouth of the river Hooghly. Brachygnatha (Oxyrhyncha and Brachyrhyncha) // Records of the Indian Museum. Vol.37. No.4. P.463-514.

Chou W.-R., Fang L.-S. 2005. The development of the decapod assemblage at a steel-slag disposal site with disturbance from a typhoon in Taiwan // Bulletin of Marine Science. Vol.76. P.637-646.

Crosnier A. 1962. Crustacés Décapodes, Portunidae // Faune de Madagascar. Tananarive: Institut de Recherche Scientifique. Vol.16. P.1-154, Pls.151-113.

Dai A.-Y., Yang S.-L. 1991. Crabs of the China Seas. Beijing, China: China Ocean Press. 682 p.

Dai A.-Y., Yang S.-L., Song Y.-Z., Chen G.-X. 1986. [Crabs of the China seas]. Beijing: China Ocean Press. P.17+642, Pls.1-74. [In Chinese]

Davie P.J.F. 1992. A trawl survey of the microbenthic Brachyuran and Anomuran (Crustacea: Decapoda) communities of Tolo Harbour, Tolo Channel and Mirs Bay // Morton B. (ed.). The marine flora and fauna of Hong Kong and southern China III Proceedings of the Fourth International Marine Biological Workshop, the Marine Flora and Fauna of Hong Kong and Southern China. Hong Kong: Hong Kong University Press. P. 483-497.

Davie P.J.F. 2002. Crustacea: Malacostraca. Eucarida (Part 2). Decapoda - Anomura, Brachyura: Zoological Catalogue of Australia. 19.3B. CSIRO Publications, Australia. $641 \mathrm{p}$.

Davie P.J.F., Guinot D., Ng P.K.L. 2015. Anatomy and functional morphology of Brachyura // Castro P., Davie P.J.F., Guinot D., Schram F.R., von Vaupel Klein J.C. (eds), Treatise on Zoology - Anatomy, Taxonomy, Biology - The Crustacea, Complementary to the Volumes Translated from the French of the Traité de Zoologie. 9 (C) (I). Decapoda: Brachyura. Part 2 Leiden: Brill. P.11-163. doi:10.1163/9789004190832004

Deb M. 1999. Crustacea: Decapoda: Crabs // Fauna of West Bengal, State Fauna Series. Kolkata: Zoological Survey of India (1998). Vol.10. No.3. P.345-403.

Dev Roy M.K. 2013. Diversity and distribution of marine bachyuran crab communities inhabiting West Coast of India // Venkataraman C., Sivaperuman, Raghunathan C. (eds.). Ecology and Conservation of Tropical Marine Faunal Communities Part 1. Berlin Heidelberg: Beijing. P.147-169.

Dev Roy M.K., Nandi N.C. 2007. Brachyuran diversity in coastal ecosystems of Tamil Nadu // Journal of Environment and Sociobiology. Vol.4. No.2. P.169-192.

Dev Roy M.K., Nandi N.C. 2008. Checklist and distribution of brachyuran crabs of West Bengal, India // Journal of Environment and Sociobiology. Vol.5. No.2. P.191-214.

Dev Roy M.K., Nandi N.C. 2012. Brachyuran crabs (Crustacea) // Fauna of Andaman and Nicobar Islands, State Fauna Series. Kolkata: Zoological Survey of India. Vol.19. No.1. P.185-236.

Dev Roy M.K., Rath S. 2017. An inventory of crustacean fauna from Odisha Coast, India // Journal of Environment and Sociobiology. Vol.14. No.1. P.49-112.

Dev Roy M.K., Rath S., Nandi N.C. 2017. A note on portunid crabs of Odisha Coast, India // Oceanography et Fisheries. Vol.1. No.3. P.1-3.

Devi K.N. 1993. Portunid crabs of Visakhapatnam coast // Journal of the Bombay Natural History Society. Vol.90. No.3. P.535-537.

Emmerson W.D. 2016. A guide to, and checklist for, the Decapoda of Namibia, South Africa and Mozambique. Volumes 1-3. Cambridge Scholars Publishing, Cambridge. Vol.1. 590 p.; Vol.2. 650 p.; Vol.3. 720 p.

Evans N. 2018. Molecular phylogenetics of swimming crabs (Portunoidea Rafinesque, 1815) supports a revised family-level classification and suggests a single derived origin of symbiotic taxa // PeerJ. Vol.6. e4260; DOI 10.7717/peerj.4260.

Fabricius J.C. 1798. Supplementum Entomologiae Systematicae. Hafniae: Proft et Storch. 572 p.

Fang S.H. 1991. [Crabs from central and northern Taiwan Strait] // Journal of Oceanography of the Taiwan Strait. Vol.10. P.351355 [in Chinese with English abstract].

Forskål P. 1775. Descriptiones Animalium Avium, Amphibiorum, Piscium, Insectorum, Vermium; quae in Itinere orientali observavit. Petrus Forskal. Hafniae. Vol.9. No.34. 164 p., map 1.

Guinot D. 1967. La faune carcinologique (Crustacea, Brachyura) de l'Ocean Indien occidental et de la Mer Rouge. Catalogue remarques biogéographiques et bibliographie // Mémoires de l'Institut fundamental d'Afrique noire. Vol.77. P.235-352.

Haan H.M. De. 1833. Crustacea // Siebold P.F., von. Fauna Japonica, sive Descriptio animalium, quae in itinere per Japoniam, jussu et auspiciis superiorum, qui summum in India Batavia imperium tenent, suscepto, annis 1823-1830 collegit, notis, observationibus a adumbrationibus illustravit. Lugduni Batavorum. Fasc.1. P.ix-xvi + 1-24. Pls.1-8+A+B+circ. tab. 2.

Haan H.M. De. 1835. Crustacea // Siebold P.F., von. Fauna Japonica, sive Descriptio animalium, quae in itinere per Japoniam, jussu et auspiciis superiorum, qui summum in India Batavia imperium tenent, suscepto, annis 1823-1830 collegit, notis, observationibus a adumbrationibus illustravit. Lugduni Batavorum. Fasc.2. P.25-64. Pls.9-15+17+C+D.

Hashmi S.S. 1964. Some additions to the check list of crabs of Karachi and notes on habit and habitat of Podophthalmus vigil (Fabricius) and Macrophthalmus sp. // Agriculture Pakistan. Vol.15. No.4. P.451-454.

Henderson J.R. 1893. A contribution to Indian carcinology // Transactions of the Linnean Society of London. Ser.2, Zoology. Vol.5. No.10. P.325-458, Pls.36-40.

Hsueh P.-W., Hung H.-T. 2009. Temporal and spatial reproductive patterns of subtidal brachyuran crabs in coastal waters of Taiwan // Crustaceana. Vol.82. No.4. P.449-465.

Hsueh P.-W., Ng P.K.L., Hung H.-T. 2006. Brachyuran crab assemblages in subtidal soft-bottom habitats of Taiwan // Journal of the Fisheries Society of Taiwan. Vol.33. P.281-294.

Huang J.-F., Yu H.-P. 1998. [Illustrations of swimming crabs from Taiwan]. Kaohsiung, Taiwan: National Museum of Marine Biology and Aquarium. 181 p. [In Chinese]

Huang Z.-G. (ed.). 1994. Brachyura // Marine species and their distributions in China's Seas. Department of Ocean Management and Monitoring State Oceanic Administration. Beijing: China Ocean Press. P.576-600.

Jeng M.-S., Jan R.-Q., Tzeng C.-S., Feng F.-L. 1997. [Survey and monitoring of natural ecological resources in the Northeast Coast National Scenic Area (III)]. Taipei, Taiwan: Northeast Coast National Scenic Area Administration, Bureau of the Ministry of Transportation and Communications. 194 p. [In Chinese]

Jeng M.-S., Shao K.-T., Tzeng C.-S., Feng F.-L., Wu S.-U. 1998. Survey and monitoring of natural ecological resources in the Northeast Coast National Scenic Area (IV). Taipei, Taiwan: Northeast Coast National Scenic Area Administration, Bureau of the Ministry of Transportation and Communications. $182 \mathrm{p}$. [In Chinese]

Karasawa H., Schweitzer C.E., Feldmann R.M. 2008. Revision of Portunoidea Rafinesque, 1815 (Decapoda: Brachyura) with emphasis on the fossil genera and families // Journal of Crustacean Biology. Vol.28. P.82-127.

Kensley B. 1981. On the zoogeography of Southern African Decapod Crustacea, with a distributional checklist of the species // Smithsonian Contributions to Zoology. Vol.338. P.1-64.

Koch M., Chong V.C., Sasekumar A., Duriš Z. 2015a. New records and range-extension of the swimming crab Xiphonectes pseudohastatoides (Yang et Tang, 2006) (Brachyura, Portunidae) // Crustaceana. Vol.88. No.6. P.641-649.

Koch M., Duriš Z. 2018. Monomia lucida sp. nov., a new swimming crab (Crustacea: Decapoda: Portunidae) from the South China Sea // Zootaxa. Vol.4387. No.3. P.567-579.

Koch M., Ďuriš Z. 2019. Xiphonectes aculeatus sp. nov., a new swimming crab (Crustacea: Decapoda: Portunidae) from Madagascar // Zootaxa. Vol.4551. No.4. P.455-462. 
Koch M., Kamanli S.A., Crimmen O., Lin C.-W., Clark P.F., Duriš Z. 2017. The identity of Monomia argentata (Crustacea: Brachyura: Portunidae) resolved by X-ray, computed tomography scanning and molecular comparisons // Invertebrate Systematics. Vol.31. P.797-811.

Koc M., Nguyen T.S., Ďuriš Z. 2015b. Monomia calla, a new species of swimming crab (Decapoda, Portunidae) from Madagascar and the Philippines // Zootaxa. Vol.3981. No.3. P.405412.

Kumar A., Sushilkumar M., Raffi S.M., Ajmalkhan S. 2007. Diversity of brachyuran crabs associated with trawl by-catch in Kerala coast, India // Indian Journal of Fisheries. Vol.54. No.3. P.283-290.

Lai S.-H., Huang J.-F., Fang L.-S. 1997. [Crab fauna of Kaohsiung Harbor, southwestern Taiwan] // Annals of the Taiwan Museum. Vol.40. P.12-21 [in Chinese with English abstract].

Laurie R.D. 1906. Report on the Brachyura collected by Professor Herdman, at Ceylon, in 1902 // Herdman W.A. (ed.). Report to the Government of Ceylon on the Pearl Oyster Fisheries of the Gulf of Manaar with Supplementary Reports Upon the Marine Biology of Ceylon by Other Naturalists. Part 5. Supplementary Reports 40. P.349-432.

Laurie R.D. 1915. Reports on the Marine Biology of the Sudanese Red Sea. XXI. On the Brachyura // Journal of the Linnean Society London (Zoology). Vol.31. P.407-475, Pls.42-45.

Lin C.C. 1949. A catalogue of brachyurous Crustacea of Taiwan // Quarterly Journal of the Taiwan Museum. Vol.2. P.10-33.

Maki M., Tsuchiya K. 1923. [A monograph of the Decapoda Crustacea of Formosa]. Taipei, Taiwan: Report of the Department of Agriculture, Government of Research Institute of Taihoku. No.3. 215 p. [In Japanese]

Man J.G. De. 1887. Report on the Podophthalmous Crustacea of the Mergui Archipelago, collected for the Trustees of the Indian Museum, Calcutta, by Dr. John Anderson, F.R.S., Superintendent of the Museum. - Part II // Journal of the Linnean Society of London (Zoology). Vol.22. No.137. P.65-128, Pls.48.

Man J.G. De. 1895. Bericht über die von Herrn Schiffscapitän Storm zu Atjeh, an den westlichen Küsten von Malakka, Borneo und Celebes sowie in der Java-See gesammelten Decapoden und Stomatopoden // Zoologische Jahrbücher, Abteilung für Systematik, Geographie und Biologie der Thiere. Bd.8. H.4 S.485-609.

Mantelatto F.L., Robles R., Felder D.L. 2007. Molecular phylogeny of the western Atlantic species of the genus Portunus (Crustacea, Brachyura, Portunidae) // Zoological Journal of the Linnean Society. Vol.150. No.1. P.211-220.

Mantelatto F.L., Robles R., Wehrtmann I.S., Schubart C.D., Felder D.L. 2018. New insights into the molecular phylogeny of the swimming crabs of the genera Portunus Weber, 1795 and Achelous De Haan, 1833 (Brachyura: Portunidae) of the Americas // Journal of Crustacean Biology. Vol.38. No.2. P.190197. doi:10.1093/jcbiol/rux119.

Mantelatto F.L., Robles R., Schubart C.D., Felder D.L. 2009. Molecular phylogeny of the genus Cronius Stimpson, 1860, with reassignment of $C$. tumidulus and several American species of Portunus to the genus Achelous De Haan, 1833 (Brachyura: Portunidae) // Martin J.W., Crandall K.A., Felder D.L. (eds.). Crustacean Issues 18: Decapod Crustacean Phylogenetics. England: CRC Press. P.567-579.

McNeill F.A. 1968. Crustacea, Decapoda and Stomatopoda // Great Barrier Reef Expedition 1928-29 Scientific Report. Vol.7. No.1. P.1-98.

Miers E.J. 1884. Crustacea // Report on the zoological collections made in the Indo-Pacific Ocean during the voyage of H.M.S Alert 1881-1882. Part I. The collections from Melanesia. London, British Museum (Natural History). P.178-322, Pls.18-32.

Miers E.J. 1886. Report on the Brachyura collected by H.M.S Challenger during the years 1873-1876 // Wyville Thomson C., Murray J. (eds.). Report on the Scientific Results of the Voyage of H.M.S. Challenger during the years 1873-1876 under the command of Captain George S. Nares, R.N., F.R.S. and the late Captain Frank Tourle Thomson, R.N. prepared under the Superintendence of the late Sir C. Wyville Thomson, Knt., F.R.S. etc. Regius Professor of Natural History in the University of Edinburgh Director of the civilian scientific staff on board and now of John Murray, LL.D., Ph.D., etc. one of the naturalists of the Expedition. Zoology. Published by Order of Her Majesty's Government, London, Edinburgh and Dublin. Vol.17(XLIX). 1 [= 50] + 362 pp.

Milne-Edwards A. 1861. Etudes zoologiques sur les Crustacés récents de la famille des Portuniens // Archives du Muséum national d'Histoire naturelle, Paris. Vol.10. P.309-428, Pls.28-38.

Moosa M.K. 1995. Crustacea Decapoda: deep-water swimming crabs from the south-west Pacific, particularly New Caledonia (Brachyura, Portunidae) // Crosnier A. (ed.). Résultats des Campagnes MUSORSTOM. Vol.15. Mémoires du Muséum national d'Histoire naturelle, Paris. Vol.168. P.503-530.

Naderloo R. 2017. Atlas of crabs of the Persian Gulf. Cham: Springer. $440 \mathrm{p}$.

Naderloo R., Sari A. 2007. Subtidal crabs of the Iranian coast of the Persian Gulf: new collections and biogeographic considerations // Aquatic Ecosystem Health and Management. Vol.10. P.341-349.

Neumann V., Spiridonov V.A. 1999. Shallow water crabs from the Western Indian Ocean: Portunoidea and Xanthoidea excluding Pilumnidae (Crustacea Decapoda Brachyura) // Tropical Zoology. Vol.12. P.9-66.

Ng P.K.L., Guinot D., Davie P.J.F. 2008. Systema Brachyurorum: Part I. An annotated checklist of extant brachyuran crabs of the world // Raffles Bulletin of Zoology. Suppl.17. P.1-286.

Ng P.K.L., Shih H.-T., Ho P.-H., Wang C.-H. 2017. An updated annotated checklist of brachyuran crabs from Taiwan (Crustacea: Decapoda) // Journal of the National Taiwan Museum. Vol.70. P.1-185. doi:10.6532/JNTM.20171270(3;4).01

Ng P.K.L., Wang C.-H., Ho P.-H., Shih H.-T. 2001. An annotated checklist of brachyuran crabs from Taiwan (Crustacea: Decapoda) // National Taiwan Museum Special Publication, Series Vol.11. P.1-86, 8 colour pls.

Nobili G. 1905. Décapodes nouveaux des côtes d'Arabie et du Golfe Persique (Diagnoses préliminaires) // Bulletin du Muséum d'Histoire naturelle, Paris. Série 1. Vol.11. No.3. P.158-164.

Nobili G. 1906a. Crustacés Décapodes et Stomatopodes // Mission J. Bonnier et Ch. Pérez (Golfe Persique 1901). Bulletin Scientifique de la France et de la Belgique. Vol.40. P.13159, Pls.2-7.

Nobili G. 1906b. Faune carcinologique de la Mer Rouge. Décapodes et Stomatopodes // Annales des Sciences Naturelles, Zoologie comprenant 1'Anatomie, la Physiologie, la Classification, et 1'histoire naturelle des Animaux. Series 9. Vol.4. Nos.1-3. P.1-347, Pls.1-11.

Sakai T. 1934. Brachyura from the Coast of Kyusyu, Japan // Science Reports of the Tokyo Bunrika Daigaku, Section B. Vol.1. No.25. P.281-330, Pls.17, 18.

Sakai T. 1935. Crabs of Japan. Tokyo: Sanseido. P.1-239, i-xxvii, 1 colour-frontispiece. Pls.1-66. [In Japanese]

Sakai T. 1939. Studies on the Crabs of Japan. IV. Brachygnatha, Brachyrhyncha. Tokyo: Yokendo. P.365-741, Pls.42-111.

Sakai T. 1965. The Crabs of the Sagami Bay collected by His Majesty the Emperor of Japan. Tokyo: Maruzen. P.i-xvi $+1-$ 206 pp. Pls.1-100, 1-92 [in Japanese] + 1-26

Sakai T. 1976. Crabs of Japan and the adjacent seas. Tokyo: Kodansha. In three volumes; English Text, pp. xxix+773 pp., Japanese text, pp. 1-461, Plates volume, pp. 1-16, pls. 1-251.

Sato H. 1936. [The collections of the littoral animals of Formosa (4)] // Botany and Zoology. Vol.4. P.1951-1957 [in Japanese].

Schubart C.D. et Reuschel S. 2009. A proposal for a new classification of Portunoidea and Cancroidea (Brachyura: Heterotremata) based on two independent molecular phylogenies // Martin J.W., Crandall K.A., Felder D.L. (eds.). Crustacean Issues 18: Decapod Crustacean Phylogenetics. England: CRC Press. P.533-549.

Sethuramalingam S., Khan A.S. 1991. Brachyuran crabs of Parangipettai Coast. Centre of Advance Study in Marine Biology, Annamalai University. 93 p. 
Shen C.J. 1937. Notes on a collection of swimming crabs (Portunidae) from Singapore // Bulletin of the Raffles Museum. Vol.13. P.96-139.

Shen C.J. 1940. The Brachyuran fauna of Hong Kong // Hong Kong Fisheries Research Station Journal. Vol.1. P.211-242.

Spiridonov V.A. 1994. The swimming crabs (Crustacea, Brachyura, Portunidae) of submerged rises and insular shelves of the Atlantic and Indian Oceans. Bottom fauna of seamounts // Transactions of the P.P. Shirshov Institute of Oceanology. Vol.129. P.126-152

Spiridonov V.A. 1999. Results of the Rumphius Biohistorical Expedition to Ambon (1990). Part 8. Swimming crabs of Ambon (Crustacea: Decapoda: Portunidae) // Zoologische Mededelingen. Vol.73. No.4. P.63-97.

Spiridonov V.A. 2020. An update of phylogenetic reconstructions, classification and morphological characters of extant Portunoidea Rafinesque, 1815 (Decapoda, Brachyura, Heterotremata), with a discussion of their relevance to fossil material // Geologija. Vol.63. No.1. P.133-166.

Spiridonov V.A., Neretina T.V., Schepetov D. 2014. Morphological characterization and molecular phylogeny of Portunoidea Rafinesque, 1815 (Crustacea Brachyura): Implications for understanding evolution of swimming capacity and revision of the family-level classification // Zoologischer Anzeiger. Vol.253. P.404-429.

Stephensen K. 1946. The Brachyura of the Iranian Gulf with an appendix: the male pleopoda of the Brachyura // Danish Scientific Investigations in Iran, 1945. Vol.4. P.57-237.

Stephenson W. 1967. The portunid crabs (Crustacea: Portunidae) collected by the Naga Expedition // Naga Report. Scientific Results of Marine Investigations of the South China Sea and the Gulf of Thailand 1959-1961. Vol.4. No.1. P.4-37.

Stephenson W. 1972a. Portunid crabs from the Indo-West-Pacific and Western America in the Zoological Museum, Copenhagen (Decapoda, Brachyura, Portunidae) // Steenstrupia. Vol.2. No.9. P.127-156.

Stephenson W. 1972b. An annotated check list and key to the IndoWest-Pacific swimming crabs (Crustacea: Decapoda: Portunidae) // Bulletin of the Royal Society of New Zealand. Vol.10. P.1-64.

Stephenson W. 1975. Biological results of the Snellius Expedition, XXVI. The Portunidae (Decapoda-Brachyura) of the Snellius Expedition (part II) // Zoologische Mededelingen. Vol.49. No.14. P.173-209.

Stephenson W. 1976. Notes on Indo-West-Pacific portunids in the Smithsonian Institution // Crustaceana. Vol.31. P.11-26.

Stephenson W., Campbell B. 1959. The Australian portunids (Crustacea: Portunidae). III. The genus Portunus // Australian Journal of Marine and Freshwater Research. Vol.11. No.1. P.84 124, Pls.1-5.

Stephenson W., Rees M. 1967a. Some portunid crabs from the Pacific and Indian Oceans in the collections of the Smithsonian Institution // Proceedings of the United States National Museum. Vol.120. P.1-114.

Stephenson W., Rees M. 1967b. Portunid crabs from the International Indian Ocean Expedition in the Smithsonian Collections (Crustacea: Portunidae) // Proceedings of the United States National Museum. Vol.122. No.3599. P.1-33.

Stephenson W., Rees M. 1967c. Portunid crabs (Crustacea: Decapoda: Portunidae) collected by the 'Discovery' in the Indian Ocean // Journal of Natural History. Vol.1. No.2. P.285-288.

Stimpson W. 1858. Prodromus descriptionis animalium evertebratorum in expeditione ad Oceanum Pacificum Septentrionalem missa, C. Ringgold et Johanne Rodgers ducibus, observatorum et descriptorum. Pars IV. Crustacea Cancroidea et Corystoidea // Proceedings of the Academy of Natural Sciences of Philadelphia. Vol.10. P.31-40 [29-37].
Stimpson W. 1907. Report on the Crustacea (Brachyura and Anomura) collected by the North Pacific Exploring Expedition 1853-1856 // Smithsonian Miscellaneous Collections. Vol.49. No.1717. P.1-240.

Thomas M.M. 1969. Catalogue of crabs and hermit-crabs in the reference collections of the central marine fisheries research institute // Bulletin of the Central Marine Fisheries Research Institute. Vol.7. P.41-50.

Tirmizi N.M., Kazmi Q.M. 1996. Marine fauna of Pakistan: 6. Crustacea: Brachyura, Brachyrhyncha part 2 (Portunidae). Karachi: Centre for Excellence in Marine Biology, University of Karachi. P.1-72. Pls.1, 2.

Titgen R.H. 1982. The systematics and ecology of the Decapods of Dubai, and their zoogeographic relationships to the Arabian College Station, Texas A et M University, PhD thesis. $269 \mathrm{p}$.

Trivedi J.N., Trivedi D.J., Vachhrajani K.D., Ng P.K.L. 2018. An annotated checklist of marine brachyuran crabs (Crustacea: Decapoda: Brachyura) of India // Zootaxa. Vol.4502. No.1. P.1-83.

Tzeng C.-S., Chen Y.-H. 1992. [Guide to the seashore life in the East Coast, National Scenic Area of Taiwan]. East Coast National Scenic Area Administration. 221 p. [In Chinese]

Wang T.-W., Chan T.-Y., Chan B.K.K. 2013a. Diversity and community structure of decapod crustaceans at hydrothermal vents and nearby deep-water fishing grounds off Kueishan Island, Taiwan: a high biodiversity deep-sea area in the NW Pacific // Bulletin of Marine Science. Vol.89. P.505-528.

Wang T.-W., Chan T.-Y., Huang C.-W., Chan B.K.K. 2013b. Thirty years of changes in the decapod community from the deepwater fishing grounds off Kueishan Island, Taiwan // Crustaceana. Vol.86. P.1382-1409.

Wang T.-W., Kuo P.-H., Lin C.-W., Huang C.-W., Chan T.-Y., Chan B.K.K. 2017. Assessing the biodiversity of deep-sea large crustaceans through fishing ports // Journal of Crustacean Biology. Vol.37. P.490-495.

Windsor A.M., Mendoza J.C.E., Deeds J.R. 2019. Resolution of the Portunus gladiator species complex: taxonomic status and identity of Monomia gladiator (Fabricius, 1798) and Monomia haanii (Stimpson, 1858) (Brachyura, Decapoda, Portunidae) // ZooKeys. Vol.858. P.11-43.

Wong K.J.H., Leung K.M.Y., Chan B.K.K. 2010. On the identities of three common shallow-water swimming crabs Portunus hastatoides Fabricius, 1798, $P$. dayawanensis Chen, 1986, and $P$. pseudohastatoides Yang and Tang, 2006 (Crustacea: Decapoda: Portunidae): Essentials for Benthic Ecological Monitoring and Biodiversity Studies // Zoological Studies. Vol.49. No.5. P.669-680

Yang S.L., Tang B.P. 2006. A new species of Portunus Weber, 1795 (Decapoda, Brachyura, Portunidae) from China // Crustaceana. Vol.79. P.691-697.

Yang S.L., Chen H.L., Dai A. 2012. Fauna Sinica: Invertebrata, Vol.49: Crustacea: Decapoda: Portunidae. Beijing: Science Press. 417 p., 14 pls.

Yokoya Y. 1933. On the distribution of Decapod Crustaceans inhabiting the continental shelf around Japan, chiefly based upon the materials collected by the S.S. Sôyô-Maru, during the year 1923-1930 // Journal of the College of Agriculture, Imperial University of Tokyo. Vol.12. No.1. P.1-226.

Yu H.P. 1979. [The swimming crabs (Crustacea, Decapoda, Portunidae) of Taiwan] // Aquiculture. Vol.2. P.41-74 [in Chinese with English abstract].

Zarenkov N.A. 1969. [On the crab family Portunidae. 2. Genus Portunus Weber] // Vestnik Moskovskogo Universiteta (Biologia), Pochovedenie. No.6. P.13-18 [in Russian].

Responsible editor I.N. Marin 